\title{
Petrogenesis of post-orogenic syenites in the Sulu Orogenic Belt, East China: geochronological, geochemical and $\mathrm{Nd}-\mathrm{Sr}$ isotopic evidence
}

\author{
Jin-Hui Yang ${ }^{\mathrm{a}, *}$, Sun-Lin Chung ${ }^{\mathrm{b}}$, Simon A. Wilde ${ }^{\mathrm{c}}, \mathrm{Fu}-\mathrm{yuan} \mathrm{Wu}^{\mathrm{a}}$, Mei-Fei Chu ${ }^{\mathrm{b}}$, \\ Ching-Hua Lo ${ }^{\mathrm{b}}$, Hong-Rui Fan ${ }^{\mathrm{a}}$ \\ anstitute of Geology and Geophysics, Chinese Academy of Sciences, P.O. Box 9825, Beijing 100029, China \\ ${ }^{\mathrm{b}}$ Department of Geosciences, National Taiwan University, Taipei 106, Taiwan \\ ${ }^{\mathrm{c}}$ Department of Applied Geology, Curtin University of Technology, Perth, Australia
}

Received 25 February 2004; accepted 26 August 2004

\begin{abstract}
The Jiazishan alkaline complex in the eastern Sulu ultrahigh pressure (UHP) metamorphic orogenic belt of eastern China is composed of potassic to ultrapotassic pyroxene syenite, quartz syenite and associated mafic dikes. A SHRIMP zircon ${ }^{206} \mathrm{~Pb} /{ }^{238} \mathrm{U}$ age of $215 \pm 5 \mathrm{Ma}$ was obtained for the quartz syenite and mineral ${ }^{40} \mathrm{Ar} /{ }^{39} \mathrm{Ar}$ dating gave emplacement ages of $214.4 \pm 0.3$ and 214.6 $\pm 0.6 \mathrm{Ma}$ for the pyroxene syenite and 200.6 $\pm 0.2 \mathrm{Ma}$ for the mafic dike. These dates establish that the Jiazishan Complex was emplaced shortly after the UHP metamorphic event at 240 to $220 \mathrm{Ma}$ due to the continental collision between the North China and Yangtze cratons. The ultrapotassic mafic dikes, with $\mathrm{K}_{2} \mathrm{O} \approx 4.4-6.4$ wt. $\%$ and $\mathrm{K}_{2} \mathrm{O} / \mathrm{Na}_{2} \mathrm{O} \approx 3.5$, have high $\mathrm{MgO}(8.06-12.44$ wt.\%), $\mathrm{Ni}(119-319 \mathrm{ppm})$ and $\mathrm{Cr}(477-873 \mathrm{ppm})$ and moderately low $\mathrm{CaO} / \mathrm{Al}_{2} \mathrm{O}_{3}(\sim 0.76)$ and $\mathrm{TiO}_{2}(\sim 1.12 \mathrm{wt} . \%)$. They also have high $\mathrm{Sr}\left({ }^{87} \mathrm{Sr}{ }^{86} \mathrm{Sr} \sim 0.7073\right)$, low $\mathrm{Nd}\left(\epsilon_{\mathrm{Nd}}=\sim-16.5\right)$ isotopic ratios, enriched LILE $(\mathrm{Ba} / \mathrm{La}=66-74)$, LREE [(La/Yb $\left.)_{N}=28-33\right]$ and depleted HFSE ( $\mathrm{La} / \mathrm{Nb}=4-6)$. It appears that the mafic dikes were derived from a refractory, re-enriched lithospheric mantle source. The syenites have Sr and Nd isotopic compositions similar to the mafic dikes, implying a common origin. Geochemical and isotopic modeling suggests that the pyroxene syenites may have been generated by early fractionation of clinopyroxene and olivine, coupled with minor amounts of crustal contamination, of a mafic magma that had a similar composition to the mafic dikes. Subsequent fractionation of feldspar-dominated assemblages, with minor or no contamination, would result in the quartz syenites. This post-orogenic magmatism, resulting most likely in an extensional setting, provides time constraints on the major geodynamic transition from convergence to extension at the eastern margin of the North China craton. The Jiazishan potassic magmatism and geodynamic transition from convergence to extension can be explained by convective removal of the lower lithospheric mantle. (C) 2004 Elsevier B.V. All rights reserved.
\end{abstract}

Keywords: Post-orogenic magmatism; Potassic to ultrapotassic magmatism; Sulu UHP belt; North China craton

* Corresponding author. Tel.: +8610 62007900; fax: +86 1062010846.

E-mail address: jinhui@mail.igcas.ac.cn (J.-H. Yang). 


\section{Introduction}

Syenites and alkaline felsic rocks are commonly intimately associated with alkaline mafic rocks, especially alkali to transitional basalts. The origin of the more evolved rocks, however, remains controversial. Models proposed for the generation of syenites may be divided into three groups. First, syenite magmas may originate by partial melting of crustal rocks resulting from an influx of volatiles (e.g., Lubala et al., 1994) or in a closed system at pressures typical of the base of over-thickened crust (Huang and Wyllie, 1981). Second, syenite magmas may be products of partial melting of metasomatized mantle (Sutcliffe et al., 1990; Lynch et al., 1993) or the residual melts formed by differentiation of alkali basalt magma (Parker, 1983; Brown and Becker, 1986; Thorpe and Tindle, 1992). Third, syenites may result by magma mixing processes, particularly mixing of basic and silicic melts with subsequent differentiation of the hybrid liquids (Barker et al., 1975; Sheppard, 1995; Zhao et al., 1995; Litvinovsky et al., 2002), or by mixing of mantle-derived, silicaundersaturated alkaline magmas with lower crustally derived granitic magmas (e.g., Dorais, 1990). This range of petrogenetic models also reflects the diversity of geological settings in which syenite magmas are generated. For example, it is generally assumed that these rocks characterize non-orogenic, within-plate environments. However, several alkaline associations, although not strictly non-orogenic, postdate orogenic episodes by a short interval of time, such as the Permian-Triassic Western Mediterranean province (Bonin et al., 1987), the Pan-African Arabian Shield (Harris, 1985), in Tibet (Turner et al., 1996; Miller et al., 1999; Williams et al., 2004) and other examples (Sylvester, 1989). In this context, it is important to undertake detailed studies on plutonic complexes where one particular mechanism of syenite magma production can be established with confidence.

The Jiazishan Complex, exposed in the Sulu ultrahigh pressure (UHP) orogenic belt of NE China and comprised of an intrusive association of basanite-pyroxene syenite-quartz syenite, is one such example. In this paper, we present petrographic, geochronological, geochemical and $\mathrm{Sr}-\mathrm{Nd}$ isotopic data for these rocks and demonstrate that the syenite magmas were mainly formed as a result of crystal fractionation from enriched lithospheric mantlederived magmas, with little or no assimilation of crustal material. Interpretation of the data leads to an integrated model of syenite genesis in a post-orogenic extensional setting.

\section{Geological setting and petrography}

\subsection{Regional context}

The Dabie-Sulu orogenic belt in east-central China (Fig. 1a) contains the largest distribution of UHP metamorphic rocks in the world, marking the collision zone between North China and Yangtze cratons (Huang, 1978; Wang et al., 1995; Cong, 1996). The Sulu terrane was offset to the north by sinistral movement on the Tanlu Fault of about 500 $\mathrm{km}$ (Xu and Zhu, 1994). Metamorphic rocks of the Sulu UHP belt are mainly amphibolite facies granitic gneisses, with subordinate amounts of coesite-bearing eclogites (e.g., Yang and Smith, 1989; Hirajima et al., 1990, 1992; Enami and Zang, 1993) and other UHP metamorphic rocks such as ultramafics (Yang et al., 1993; Zhang et al., 1994), marbles (Kato et al., 1997), pelitic schists (Zhang et al., 1995) and meta-granitoids (Hirajima et al., 1992). These UHP metamorphic rocks occur as sporadic lenticular bodies in the regional granitic gneisses. The margins of most eclogite lenses are transformed to amphibolite and reveal a significant amphibolite facies overprint after UHP metamorphism (Yao et al., 2000). While deep subduction of the Yangtze continental crust to over $120 \mathrm{~km}$ is evident from the occurrence of microdiamond in eclogites (Xu et al., 1992), exhumation of more deeper rocks from over $200 \mathrm{~km}$ was deduced from exsolution minerals in eclogitic garnet (Ye et al., 2000). Abundant $\mathrm{Sm}-\mathrm{Nd}$ mineral isochron and $\mathrm{U}-\mathrm{Pb}$ zircon ages have documented that the continental collision and UHP metamorphism took place in the Early-Middle Triassic at 240-220 Ma (e.g., Ames et al., 1993; Li et al., 1993a,b; Chavagnac and Jahn, 1996; Hacker et al., 1998; Zheng et al., 2002; Liu et al., 2004).

High-K calc-alkaline granitic rocks are widely distributed in the Sulu orogenic belt, but most of them formed in the Late Jurassic (160-150 Ma) and 


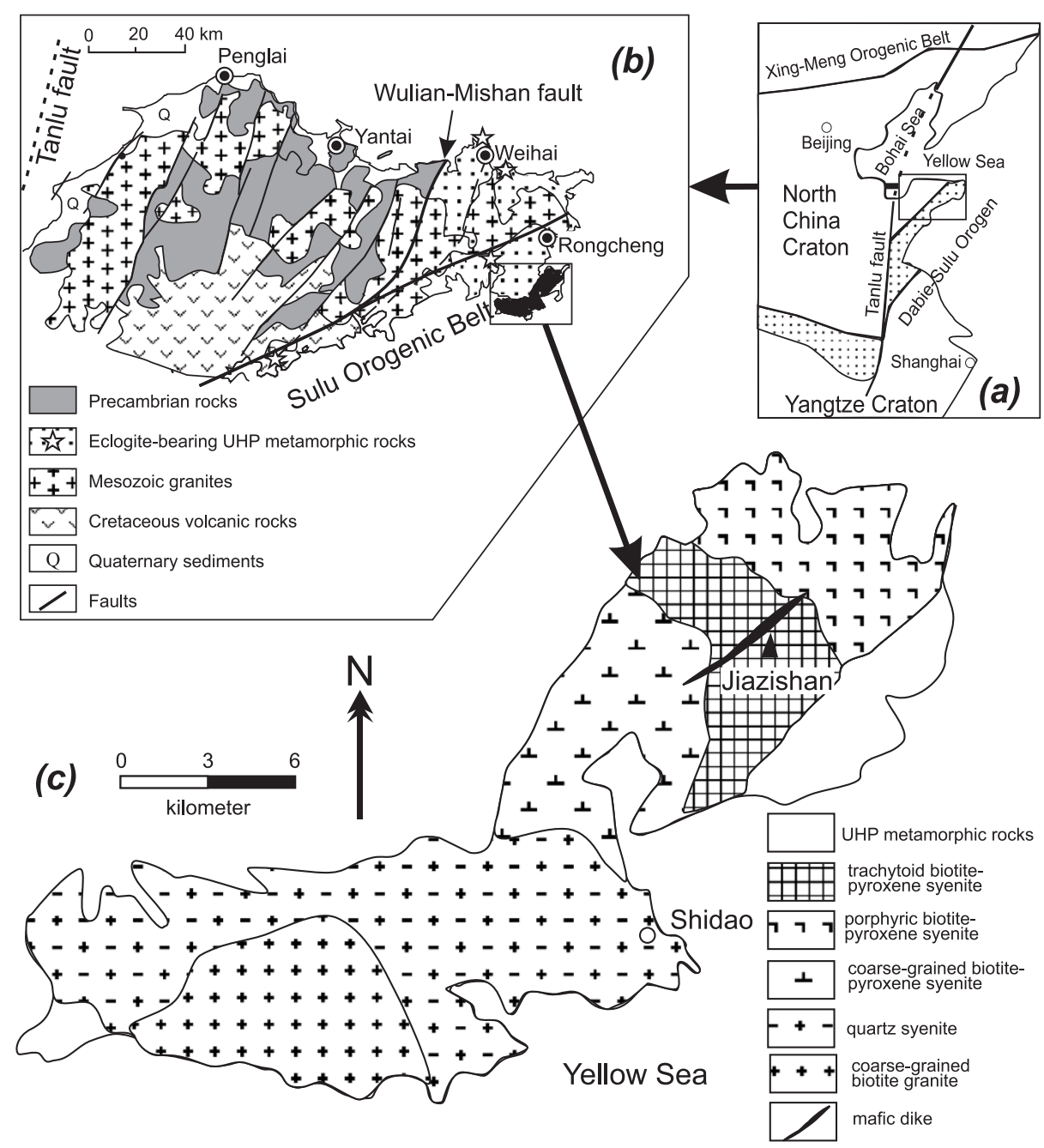

Fig. 1. Location maps showing position of the Jiazishan Complex in eastern China. (a) Relation to the Dabie-Sulu ultrahigh pressure metamorphic belt; (b) position within the Jiaodong Peninsula and (c) distribution of components in the Jiazishan Complex.

Early Cretaceous (130-125 Ma) (Wang et al., 1998; Zhang et al., 2003). Only one syenitic complexthe Jiazishan Complex - has been reported to be of Late Triassic age (Lin et al., 1992; Chen et al., 2003).

\subsection{Jiazishan syenites}

The Jiazishan Complex, located in the Jiaodong Peninsula (East China) and intruded into the Sulu UHP metamorphic belt, is one of the easternmost outcrops in the Sulu UHP metamorphic belt (Fig. 1b). It covers an area of $\sim 140 \mathrm{~km}^{2}$ and comprises at least two magmatic sequences (Lin et al., 1992). Field mapping and detailed description of the Jiazishan rocks reveal the following sequence of magmatic events: (1) intrusion of pyroxene syenite and quartz syenite; (2) intrusion of biotite granite into the syenite and (3) intrusion of mafic dikes into the syenite.

Five alkaline phases (Fig. 1c) are distinguished in the complex according to field and petrographic data.

Phase 1 is a trachytoid biotite-pyroxene syenite. Samples (JZS-11 and JZS-12) from phase 1 are composed of 54-68\% subhedral alkali feldspar, 16$26 \%$ plagioclase (with composition $\mathrm{An}_{51-55}$ ), 2-11\% 
biotite, 5-12\% amphibole and 2-8\% pyroxene, with minor olivine, titanite and magnetite. The rocks are porphyritic and characterized by phenocrysts of pyroxene and perthitic alkali feldspar. Alkali feldspar laths define a subparallel flow direction. Perthitic tectures are abundant including mesoperthite intergrowth of alkali and plagioclase feldspar and microperthite exsolution intergrowth of sodiumand potassium-rich feldspars. Plagioclase is weakly sericitized.

Phase 2 is a porphyritic biotite-pyroxene syenite. Samples (JZS-7 to JZS-10 in Table 3) are from this phase. The rocks are medium- to coarse-grained and porphyritic, consisting of up to $35 \%$ phenocrysts of perthitic alkali feldspar in a microcrystalline groundmass of $4-6 \%$ pyroxene, $3-9 \%$ biotite, $8-25 \%$ plagioclase and $40-50 \%$ alkali feldspar. Minor olivine $(<1 \%)$ is found as inclusions in the pyroxene. Some pyroxenes are also altered to hornblende. Alkali-feldspar phenocrysts range from 2 to $7 \mathrm{~cm}$ long and some grains are concentrically zoned. Mafic enclaves (samples JZS-7-1 and JZS-8-1) are also common in this phase and have similar mineral assemblages to the syenites, but with more abundant mafic minerals including biotite, hornblende, olivine and pyroxene. Plagioclase is weakly sericitized.

Phase 3 is a coarse-grained biotite-pyroxene syenite. Samples (JZS-13 to 17 in Table 3) from this phase have similar mineralogy to the trachytoid biotite-pyroxene syenite.

Phase 4 is a quartz syenite. Samples (JZS-1 to JZS6 in Table 3) from this phase have 70\% alkali feldspar, $10 \%$ plagioclase (with composition $\mathrm{An}_{20-22}$ ) and $10 \%$ quartz, with accessory amphibole, clinopyroxene, apatite, titanite and magnetite. Perthitic alkali feldspars are observed as inclusions in non-perthitic varieties. Quartz occurs as inclusions in the alkali feldspar or as anhedral grains interstitial to other minerals.

Phase 5 is a mafic dike that intruded into the syenites. Samples JZS-D-2 to JZS-D-5 are from this phase and are characterized by local phenocrysts of pyroxene and minor biotite in a groundmass of 35\% pyroxene, $35 \%$ alkali feldspar, $10 \%$ olivine, 5\% plagioclase, $5 \%$ hornblende and $10 \%$ biotite. The rocks have a massive texture. Plagioclase is weakly sericitized and olivine is locally replaced by iddingsite.
Lin et al. (1992) determined the age of the pyroxene syenite and intrusive biotite granite as 220-217 Ma, using whole rock and biotite $\mathrm{Rb}-\mathrm{Sr}$ geochronology, but they did not relate the origin of the complex to the overall development of the UHP belt. Guo et al., (2001b) and Chen et al. (2003) reported zircon $\mathrm{U}-\mathrm{Pb}$ ages of $225-205 \mathrm{Ma}$ for the pyroxene syenite, but no detailed geochemical data were presented.

\section{Analytical methods}

\subsection{Zircon SHRIMP $U-P b$ dating}

SHRIMP U-Pb zircon analyses were performed at Curtin University of Technology. Sample preparation and basic operating procedures are described by Nelson (1997). An average mass resolution of 4800 was obtained during measurement of the $\mathrm{Pb} / \mathrm{Pb}$ and $\mathrm{Pb} / \mathrm{U}$ isotopic ratios and $\mathrm{Pb} / \mathrm{U}$ ratios were normalized to those measured on the standard zircon [CZ3$\left.\left({ }^{206} \mathrm{~Pb} /{ }^{238} \mathrm{U}=0.0914\right)\right]$, with the calibration error on the standards being $1.54 \%$. The ${ }^{206} \mathrm{~Pb} /{ }^{238} \mathrm{U}$ ages are considered the most reliable, since the zircons are concordant and the low count rates on ${ }^{207} \mathrm{~Pb}$ result in large statistical uncertainties, making the ${ }^{207} \mathrm{~Pb} /{ }^{206} \mathrm{~Pb}$ and ${ }^{207} \mathrm{~Pb} /{ }^{235} \mathrm{U}$ ratios less sensitive measures of age for younger zircons (Compston et al., 1992). The measured ${ }^{204} \mathrm{~Pb}$ on the zircons was similar to the standard, and therefore common lead corrections were made assuming an isotopic composition of Broken Hill lead, since common lead is considered to be mainly related to surface contamination (Nelson, 1997). Data reduction was performed using the Krill 007 program of P.D. Kinny applying the ${ }^{208} \mathrm{~Pb}$ correction, since there is no evidence of postcrystallization disturbance to the $\mathrm{U}-\mathrm{Pb}-\mathrm{Th}$ system. Errors on individual analyses are at the $1 \sigma$ level (Table 1) and errors on pooled analyses are quoted at $2 \sigma$ or $95 \%$ confidence.

\section{2. ${ }^{40} \mathrm{Ar} /{ }^{39} \mathrm{Ar}$ dating}

Hornblende, K-feldspar and whole rock samples from the Jiazishan Complex were dated by ${ }^{40} \mathrm{Ar} /{ }^{39} \mathrm{Ar}$ step-heating and single-grain fusion methods using furnace and laser heating techniques. 
Table 1

SHRIMP zircon U/Pb isotopic data for quartz syenite (JZS-3) from Jiazishan Complex

\begin{tabular}{|c|c|c|c|c|c|c|c|c|c|c|c|c|c|c|c|c|c|c|c|c|}
\hline \multirow[t]{2}{*}{ Spot } & \multirow{2}{*}{$\begin{array}{l}\mathrm{U} \\
(\mathrm{ppm})\end{array}$} & \multirow{2}{*}{$\begin{array}{l}\text { Th } \\
\text { (ppm) }\end{array}$} & \multirow{2}{*}{$\begin{array}{l}\mathrm{Th} / \\
\mathrm{U}\end{array}$} & \multirow{2}{*}{$\begin{array}{l}\mathrm{Pb} \\
(\mathrm{ppm})\end{array}$} & \multirow{2}{*}{$\begin{array}{l}{ }^{204} \mathrm{~Pb} / \\
{ }^{206} \mathrm{~Pb}\end{array}$} & \multirow[t]{2}{*}{$\mathrm{f} 206 \%$} & \multirow{2}{*}{$\begin{array}{l}{ }^{207} \mathrm{~Pb}^{\mathrm{a} /} \\
{ }^{206} \mathrm{~Pb}^{\mathrm{a}}\end{array}$} & \multirow[t]{2}{*}{ $\pm 1 \sigma$} & \multirow{2}{*}{$\begin{array}{l}{ }^{208} \mathrm{~Pb}^{\mathrm{a} /} \\
{ }^{206} \mathrm{~Pb}^{\mathrm{a}}\end{array}$} & \multirow{2}{*}{ $\pm 1 \sigma$} & \multirow{2}{*}{$\begin{array}{l}{ }^{206} \mathrm{~Pb}^{\mathrm{a}} / \\
{ }^{23} \mathrm{U}\end{array}$} & \multirow{2}{*}{ $\pm 1 \sigma$} & \multirow{2}{*}{$\begin{array}{l}{ }^{207} \mathrm{~Pb}^{\mathrm{a}} / \\
{ }^{235} \mathrm{U}\end{array}$} & \multirow{2}{*}{ $\pm 1 \sigma$} & \multirow{2}{*}{$\begin{array}{l}{ }^{208} \mathrm{~Pb}^{\mathrm{a}} / \\
{ }^{232} \mathrm{Th}\end{array}$} & \multirow{2}{*}{ $\pm 1 \sigma$} & \multicolumn{4}{|c|}{ Age $\pm 1 \sigma(\mathrm{Ma})$} \\
\hline & & & & & & & & & & & & & & & & & $\begin{array}{l}{ }^{206} \mathrm{~Pb}^{\mathrm{a} /} \\
{ }^{238} \mathrm{U}\end{array}$ & $\begin{array}{l}{ }^{207} \mathrm{~Pb}^{\mathrm{a} /} \\
{ }^{235} \mathrm{U}\end{array}$ & $\begin{array}{l}{ }^{207} \mathrm{~Pb}^{\mathrm{a}} / \\
{ }^{206} \mathrm{~Pb}^{\mathrm{a}}\end{array}$ & $\begin{array}{l}{ }^{208} \mathrm{~Pb}^{\mathrm{a} /} \\
{ }^{232} \mathrm{Th}\end{array}$ \\
\hline JZS-3-1 & 475 & 435 & 0.92 & 20 & 0.00118 & 1.893 & 0.04223 & 0.00412 & 0.2692 & 0.0100 & 0.0343 & 0.0007 & 0.20 & 0.02 & 0.0101 & 0.0004 & $217 \pm 4$ & $185 \pm 17$ & $0 \pm 43$ & $203 \pm 8$ \\
\hline JZS-3-2 & 662 & 633 & 0.96 & 26 & 0.00016 & 0.249 & 0.05056 & 0.00198 & 0.2992 & 0.0053 & 0.0335 & 0.0006 & 0.23 & 0.01 & 0.0105 & 0.0003 & $213 \pm 4$ & $213 \pm 9$ & $221 \pm 91$ & $211 \pm 5$ \\
\hline JZS-3-3 & 720 & 1404 & 1.95 & 35 & 0.00015 & 0.235 & 0.04842 & 0.00159 & 0.6082 & 0.0060 & 0.0341 & 0.0006 & 0.23 & 0.01 & 0.0106 & 0.0002 & $216 \pm 4$ & $208 \pm 7$ & $120 \pm 74$ & $214 \pm 4$ \\
\hline JZS-3-4 & 83 & 61 & 0.73 & 4 & 0.00392 & 6.269 & 0.06075 & 0.02282 & 0.3084 & 0.0534 & 0.0300 & 0.0010 & 0.25 & 0.10 & 0.0126 & 0.0022 & $190 \pm 6$ & $227 \pm 78$ & $630 \pm 652$ & $253 \pm 44$ \\
\hline JZS-3-5 & 429 & 605 & 1.41 & 16 & 0.00085 & 1.357 & 0.06113 & 0.00544 & 0.4803 & 0.0140 & 0.0264 & 0.0005 & 0.22 & 0.02 & 0.0090 & 0.0003 & $168 \pm 3$ & $204 \pm 17$ & $644 \pm 192$ & $181 \pm 6$ \\
\hline JZS-3-6 & 38 & 78 & 2.08 & 2 & 0.00474 & 7.579 & 0.02887 & 0.04208 & 0.6184 & 0.1033 & 0.0311 & 0.0017 & 0.12 & 0.18 & 0.0092 & 0.0016 & $198 \pm 10$ & $119 \pm 152$ & $0 \pm 107$ & $186 \pm 33$ \\
\hline JZS-3-7 & 186 & 623 & 3.35 & 11 & 0.00001 & 0.012 & 0.05443 & 0.00499 & 1.0196 & 0.0189 & 0.0333 & 0.0007 & 0.25 & 0.02 & 0.0101 & 0.0003 & $211 \pm 4$ & $226 \pm 20$ & $389 \pm 207$ & $203 \pm 6$ \\
\hline JZS-3-8 & 260 & 675 & 2.59 & 14 & 0.00120 & 1.914 & 0.04053 & 0.00514 & 0.7849 & 0.0162 & 0.0324 & 0.0007 & 0.18 & 0.02 & 0.0098 & 0.0003 & $205 \pm 4$ & $169 \pm 20$ & $0 \pm 61$ & $197 \pm 6$ \\
\hline JZS-3-9 & 274 & 656 & 2.40 & 15 & 0.00038 & 0.611 & 0.04963 & 0.00486 & 0.7399 & 0.0148 & 0.0343 & 0.0007 & 0.23 & 0.02 & 0.0106 & 0.0003 & $217 \pm 4$ & $214 \pm 20$ & $178 \pm 213$ & $213 \pm 6$ \\
\hline JZS-3-10 & 773 & 1693 & 2.19 & 39 & 0.00010 & 0.155 & 0.05145 & 0.00175 & 0.6587 & 0.0064 & 0.0339 & 0.0006 & 0.24 & 0.01 & 0.0102 & 0.0002 & $215 \pm 4$ & $219 \pm 8$ & $261 \pm 78$ & $205 \pm 4$ \\
\hline JZS-3-11 & 56 & 92 & 1.65 & 3 & 0.00188 & 3.015 & 0.04462 & 0.01722 & 0.4668 & 0.0429 & 0.0331 & 0.0011 & 0.20 & 0.08 & 0.0094 & 0.0009 & $210 \pm 7$ & $188 \pm 67$ & $0 \pm 107$ & $188 \pm 18$ \\
\hline JZS-3-12 & 1074 & 2763 & 2.57 & 62 & 0.00016 & 0.260 & 0.04816 & 0.00141 & 0.8097 & 0.0061 & 0.0357 & 0.0006 & 0.24 & 0.01 & 0.0112 & 0.0002 & $226 \pm 4$ & $216 \pm 7$ & $108 \pm 65$ & $226 \pm 4$ \\
\hline JZS-3-13 & 470 & 815 & 1.73 & 22 & 0.00000 & 0.000 & 0.05447 & 0.00112 & 0.5614 & 0.0060 & 0.0344 & 0.0006 & 0.26 & 0.01 & 0.0111 & 0.0002 & $218 \pm 4$ & $233 \pm 6$ & $391 \pm 46$ & $224 \pm 5$ \\
\hline JZS-3-14 & 118 & 233 & 1.98 & 6 & 0.00057 & 0.912 & 0.05243 & 0.00899 & 0.6095 & 0.0243 & 0.0344 & 0.0008 & 0.25 & 0.04 & 0.0106 & 0.0005 & $218 \pm 5$ & $226 \pm 36$ & $304 \pm 350$ & $214 \pm 10$ \\
\hline
\end{tabular}

${ }^{a}$ Radiogenic lead. 
Table 2

${ }^{40} \mathrm{Ar} /{ }^{39} \mathrm{Ar}$ data for $\mathrm{K}$-feldspar, hornblende and whole rocks for the pyroxene syenites and mafic dike from the Jiazishan Complex

\begin{tabular}{|c|c|c|c|c|c|c|c|c|c|}
\hline \multicolumn{10}{|c|}{ JZS-13 amphibole } \\
\hline$T\left({ }^{\circ} \mathrm{C}\right)$ & Cum. 39 & ${ }^{36} \mathrm{Ar} /{ }^{39} \mathrm{Ar}$ & ${ }^{37} \mathrm{Ar} /{ }^{39} \mathrm{Ar}$ & ${ }^{38} \mathrm{Ar} /{ }^{39} \mathrm{Ar}$ & ${ }^{40} \mathrm{Ar} /{ }^{39} \mathrm{Ar}$ & ${ }^{40} \mathrm{Ar} /{ }^{36} \mathrm{Ar}$ & $\mathrm{Ca} / \mathrm{K}$ & Date (Ma) & $1 \sigma$ \\
\hline 650 & 0.019 & $8.59 \mathrm{e}-01$ & $4.87 \mathrm{e}-01$ & $5.02 \mathrm{e}-01$ & $3.20 \mathrm{e}+02$ & $3.72 \mathrm{e}+02$ & 1.62 & 317.3 & 3.7 \\
\hline 725 & 0.079 & $1.62 \mathrm{e}-01$ & $6.12 \mathrm{e}-01$ & $1.40 \mathrm{e}-01$ & $8.88 \mathrm{e}+01$ & $5.50 \mathrm{e}+02$ & 2.04 & 204.2 & 4.5 \\
\hline 800 & 0.103 & $4.42 \mathrm{e}-02$ & $1.43 \mathrm{e}-04$ & $1.43 \mathrm{e}-04$ & $5.66 \mathrm{e}+01$ & $1.28 \mathrm{e}+03$ & 0.00 & 215.5 & 2.7 \\
\hline 850 & 0.128 & $2.57 \mathrm{e}-02$ & $7.80 \mathrm{e}-02$ & $1.31 \mathrm{e}-04$ & $5.09 \mathrm{e}+01$ & $1.98 \mathrm{e}+03$ & 0.26 & 214.6 & 5.4 \\
\hline 900 & 0.154 & $2.07 \mathrm{e}-02$ & $4.39 \mathrm{e}-01$ & $1.29 \mathrm{e}-04$ & $4.99 \mathrm{e}+01$ & $2.42 \mathrm{e}+03$ & 1.46 & 217.1 & 3.0 \\
\hline 925 & 0.176 & $2.28 \mathrm{e}-02$ & $8.85 \mathrm{e}-01$ & $1.54 \mathrm{e}-04$ & $5.03 \mathrm{e}+01$ & $2.21 \mathrm{e}+03$ & 2.95 & 215.9 & 4.2 \\
\hline 950 & 0.214 & $3.63 \mathrm{e}-02$ & $1.69 \mathrm{e}+00$ & $1.97 \mathrm{e}-02$ & $5.00 \mathrm{e}+01$ & $1.38 \mathrm{e}+03$ & 5.63 & 196.1 & 3.0 \\
\hline 975 & 0.240 & $1.91 \mathrm{e}-02$ & $4.46 \mathrm{e}+00$ & $4.30 \mathrm{e}-02$ & $5.08 \mathrm{e}+01$ & $2.66 \mathrm{e}+03$ & 14.88 & 225.1 & 2.8 \\
\hline 1000 & 0.287 & $2.60 \mathrm{e}-02$ & $6.66 \mathrm{e}+00$ & $1.71 \mathrm{e}-01$ & $5.13 \mathrm{e}+01$ & $1.98 \mathrm{e}+03$ & 22.28 & 219.4 & 2.1 \\
\hline 1025 & 0.364 & $2.01 \mathrm{e}-02$ & $7.16 \mathrm{e}+00$ & $2.24 \mathrm{e}-01$ & $4.94 \mathrm{e}+01$ & $2.46 \mathrm{e}+03$ & 23.94 & 218.8 & 1.0 \\
\hline 1050 & 0.451 & $1.51 \mathrm{e}-02$ & $6.85 \mathrm{e}+00$ & $2.22 \mathrm{e}-01$ & $4.70 \mathrm{e}+01$ & $3.11 \mathrm{e}+03$ & 22.90 & 214.1 & 1.2 \\
\hline 1075 & 0.569 & $8.05 \mathrm{e}-03$ & $6.83 \mathrm{e}+00$ & $2.49 \mathrm{e}-01$ & $4.54 \mathrm{e}+01$ & $5.64 \mathrm{e}+03$ & 22.82 & 216.2 & 1.1 \\
\hline 1100 & 0.695 & $6.77 \mathrm{e}-03$ & $6.41 \mathrm{e}+00$ & $2.42 \mathrm{e}-01$ & $4.46 \mathrm{e}+01$ & $6.58 \mathrm{e}+03$ & 21.44 & 214.1 & 1.4 \\
\hline 1150 & 0.792 & $7.06 \mathrm{e}-03$ & $6.05 \mathrm{e}+00$ & $2.13 \mathrm{e}-01$ & $4.43 \mathrm{e}+01$ & $6.27 \mathrm{e}+03$ & 20.20 & 212.3 & 0.7 \\
\hline 1200 & 0.899 & $1.07 \mathrm{e}-02$ & $6.83 \mathrm{e}+00$ & $2.26 \mathrm{e}-01$ & $4.50 \mathrm{e}+01$ & $4.19 \mathrm{e}+03$ & 22.83 & 210.8 & 1.1 \\
\hline 1400 & 1.000 & $3.14 \mathrm{e}-02$ & $1.16 \mathrm{e}+01$ & $2.60 \mathrm{e}-01$ & $5.15 \mathrm{e}+01$ & $1.64 \mathrm{e}+03$ & 38.84 & 215.0 & 1.2 \\
\hline
\end{tabular}

Sample mass $=402.3 \mathrm{mg} ; J$-value $=0.002917 \pm 0.000003$; Integrated date $=215.7 \pm 0.5 \mathrm{Ma}\left({ }^{39} \mathrm{Ar}\right.$ volume $=0.1559 \mathrm{e}-11 \mathrm{ccSTP} / \mathrm{g} ;{ }^{40} \mathrm{Ar} *$ volume $=$ $0.6787 \mathrm{e}-10 \mathrm{ccSTP} / \mathrm{g}) ;$ Plateau age $=214.6 \pm 0.6 \mathrm{Ma}\left(1000-1400{ }^{\circ} \mathrm{C} ; 71.3 \%{ }^{39} \mathrm{Ar}\right)$.

JZS-11 K-feldspar

\begin{tabular}{lllllllll}
\hline$T\left({ }^{\circ} \mathrm{C}\right)$ & Cum. 39 & ${ }^{36} \mathrm{Ar} /{ }^{39} \mathrm{Ar}$ & ${ }^{37} \mathrm{Ar} /{ }^{39} \mathrm{Ar}$ & ${ }^{38} \mathrm{Ar} /{ }^{39} \mathrm{Ar}$ & ${ }^{40} \mathrm{Ar} /{ }^{39} \mathrm{Ar}$ & ${ }^{40} \mathrm{Ar} /{ }^{36} \mathrm{Ar}$ & $\mathrm{Date}(\mathrm{Ma})$ & $1 \sigma$ \\
\hline 600 & 0.008 & $8.09 \mathrm{e}-05$ & $8.09 \mathrm{e}-05$ & $8.09 \mathrm{e}-05$ & $5.73 \mathrm{e}+01$ & $7.08 \mathrm{e}+05$ & 278.7 \\
700 & 0.115 & $5.97 \mathrm{e}-06$ & $6.30 \mathrm{e}-02$ & $1.18 \mathrm{e}-02$ & $4.05 \mathrm{e}+01$ & $6.78 \mathrm{e}+06$ & 201.2 \\
800 & 0.230 & $5.59 \mathrm{e}-06$ & $5.70 \mathrm{e}-02$ & $3.66 \mathrm{e}-03$ & $4.10 \mathrm{e}+01$ & $7.34 \mathrm{e}+06$ & 203.7 \\
850 & 0.247 & $3.70 \mathrm{e}-05$ & $3.70 \mathrm{e}-05$ & $3.70 \mathrm{e}-05$ & $3.90 \mathrm{e}+01$ & $1.06 \mathrm{e}+06$ & 194.3 \\
900 & 0.299 & $1.23 \mathrm{e}-05$ & $4.55 \mathrm{e}-02$ & $1.23 \mathrm{e}-05$ & $4.06 \mathrm{e}+01$ & $3.31 \mathrm{e}+06$ & 201.9 \\
950 & 0.330 & $2.08 \mathrm{e}-05$ & $3.42 \mathrm{e}-03$ & $2.08 \mathrm{e}-05$ & $4.03 \mathrm{e}+01$ & $1.94 \mathrm{e}+06$ & 200.3 \\
1000 & 0.352 & $2.88 \mathrm{e}-05$ & $2.88 \mathrm{e}-05$ & $2.88 \mathrm{e}-05$ & $4.07 \mathrm{e}+01$ & $1.42 \mathrm{e}+06$ & 202.4 \\
1025 & 0.415 & $1.02 \mathrm{e}-05$ & $1.69 \mathrm{e}-02$ & $2.35 \mathrm{e}-03$ & $4.22 \mathrm{e}+01$ & $4.15 \mathrm{e}+06$ & 209.2 \\
1075 & 0.484 & $9.29 \mathrm{e}-06$ & $1.84 \mathrm{e}-02$ & $7.36 \mathrm{e}-03$ & $4.31 \mathrm{e}+01$ & $4.64 \mathrm{e}+06$ & 213.5 \\
1100 & 0.546 & $1.03 \mathrm{e}-05$ & $1.69 \mathrm{e}-02$ & $6.29 \mathrm{e}-03$ & $4.31 \mathrm{e}+01$ & $4.18 \mathrm{e}+06$ & 213.5 \\
1125 & 0.647 & $6.33 \mathrm{e}-06$ & $2.16 \mathrm{e}-02$ & $1.38 \mathrm{e}-02$ & $4.35 \mathrm{e}+01$ & $6.87 \mathrm{e}+06$ & 215.3 \\
1175 & 0.791 & $4.69 \mathrm{e}-06$ & $1.39 \mathrm{e}-02$ & $1.13 \mathrm{e}-02$ & $4.33 \mathrm{e}+01$ & $9.23 \mathrm{e}+06$ & 214.4 & 0.9 \\
1200 & 0.861 & $9.17 \mathrm{e}-06$ & $3.22 \mathrm{e}-03$ & $1.72 \mathrm{e}-03$ & $4.34 \mathrm{e}+01$ & $4.73 \mathrm{e}+06$ & 214.7 \\
1220 & 0.923 & $1.04 \mathrm{e}-05$ & $3.41 \mathrm{e}-05$ & $9.32 \mathrm{e}-04$ & $4.35 \mathrm{e}+01$ & $4.20 \mathrm{e}+06$ & 215.3 \\
1270 & 0.933 & $6.28 \mathrm{e}-05$ & $6.28 \mathrm{e}-05$ & $6.28 \mathrm{e}-05$ & $4.21 \mathrm{e}+01$ & $6.71 \mathrm{e}+05$ & 208.9 \\
1350 & 0.964 & $2.05 \mathrm{e}-05$ & $2.05 \mathrm{e}-05$ & $2.05 \mathrm{e}-05$ & $4.41 \mathrm{e}+01$ & $2.15 \mathrm{e}+06$ & 218.1 \\
1400 & 0.978 & $4.62 \mathrm{e}-05$ & $4.62 \mathrm{e}-05$ & $4.62 \mathrm{e}-05$ & $4.47 \mathrm{e}+01$ & $9.69 \mathrm{e}+05$ & 221.0 \\
1600 & 1.000 & $2.91 \mathrm{e}-05$ & $2.91 \mathrm{e}-05$ & $2.91 \mathrm{e}-05$ & $4.90 \mathrm{e}+01$ & $1.68 \mathrm{e}+06$ & 0.3 \\
\hline
\end{tabular}

Sample mass $=305.6 \mathrm{mg} ; J$-value $=0.002917 \pm 0.000003$; Integrated date $=211.0 \pm 0.2 \mathrm{Ma}\left({ }^{39} \mathrm{Ar}\right.$ volume $=0.1074 \mathrm{e}-10 \mathrm{ccSTP} / \mathrm{g} ;{ }^{40} \mathrm{Ar} *$ volume $=$ $0.4568 \mathrm{e}-09 \mathrm{ccSTP} / \mathrm{g})$; Plateau age $=214.4 \pm 0.3 \mathrm{Ma}\left(1075-1220{ }^{\circ} \mathrm{C} ; 50.8 \%{ }^{39} \mathrm{Ar}\right)$.

JZS-D-01 whole rock

\begin{tabular}{|c|c|c|c|c|c|c|c|c|c|}
\hline$T\left({ }^{\circ} \mathrm{C}\right)$ & Cum. 39 & ${ }^{36} \mathrm{Ar} /{ }^{39} \mathrm{Ar}$ & ${ }^{37} \mathrm{Ar} /{ }^{39} \mathrm{Ar}$ & ${ }^{38} \mathrm{Ar} /{ }^{39} \mathrm{Ar}$ & ${ }^{40} \mathrm{Ar} /{ }^{39} \mathrm{Ar}$ & ${ }^{40} \mathrm{Ar} /{ }^{36} \mathrm{Ar}$ & $\mathrm{Ca} / \mathrm{K}$ & Date (Ma) & $1 \sigma$ \\
\hline 400 & 0.003 & $2.22 \mathrm{e}-04$ & $2.22 \mathrm{e}-04$ & $2.22 \mathrm{e}-04$ & $2.99 \mathrm{e}+01$ & $1.35 \mathrm{e}+05$ & 0.00 & 150.6 & 2.4 \\
\hline 450 & 0.005 & $3.33 \mathrm{e}-04$ & $3.33 \mathrm{e}-04$ & $3.33 \mathrm{e}-04$ & $3.65 \mathrm{e}+01$ & $1.10 \mathrm{e}+05$ & 0.00 & 182.1 & 6.1 \\
\hline 500 & 0.009 & $1.52 \mathrm{e}-04$ & $1.52 \mathrm{e}-04$ & $1.52 \mathrm{e}-04$ & $3.41 \mathrm{e}+01$ & $2.25 \mathrm{e}+05$ & 0.00 & 170.7 & 7.2 \\
\hline 600 & 0.029 & $7.32 \mathrm{e}-04$ & $8.97 \mathrm{e}-02$ & $3.29 \mathrm{e}-05$ & $3.24 \mathrm{e}+01$ & $4.42 \mathrm{e}+04$ & 0.30 & 161.7 & 0.4 \\
\hline 650 & 0.076 & $2.56 \mathrm{e}-04$ & $1.63 \mathrm{e}-01$ & $1.66 \mathrm{e}-02$ & $3.60 \mathrm{e}+01$ & $1.41 \mathrm{e}+05$ & 0.54 & 179.7 & 0.3 \\
\hline
\end{tabular}


Table 2 (continued)

\begin{tabular}{|c|c|c|c|c|c|c|c|c|c|}
\hline \multicolumn{10}{|c|}{ JZS-D-01 whole rock } \\
\hline$T\left({ }^{\circ} \mathrm{C}\right)$ & Cum. 39 & ${ }^{36} \mathrm{Ar} /{ }^{39} \mathrm{Ar}$ & ${ }^{37} \mathrm{Ar} /{ }^{39} \mathrm{Ar}$ & ${ }^{38} \mathrm{Ar} /{ }^{39} \mathrm{Ar}$ & ${ }^{40} \mathrm{Ar} /{ }^{39} \mathrm{Ar}$ & ${ }^{40} \mathrm{Ar} /{ }^{36} \mathrm{Ar}$ & $\mathrm{Ca} / \mathrm{K}$ & Date $(\mathrm{Ma})$ & $1 \sigma$ \\
\hline 700 & 0.168 & $1.84 \mathrm{e}-03$ & $1.16 \mathrm{e}-01$ & $4.60 \mathrm{e}-02$ & $3.97 \mathrm{e}+01$ & $2.16 \mathrm{e}+04$ & 0.38 & 195.1 & 0.4 \\
\hline 760 & 0.234 & $9.84 \mathrm{e}-06$ & $5.18 \mathrm{e}-02$ & $4.52 \mathrm{e}-02$ & $3.97 \mathrm{e}+01$ & $4.03 e+06$ & 0.17 & 197.3 & 0.9 \\
\hline 840 & 0.340 & $6.10 \mathrm{e}-06$ & $1.20 \mathrm{e}-01$ & $4.65 \mathrm{e}-02$ & $3.93 \mathrm{e}+01$ & $6.45 \mathrm{e}+06$ & 0.40 & 195.6 & 0.5 \\
\hline 900 & 0.376 & $1.82 \mathrm{e}-05$ & $1.11 \mathrm{e}-01$ & $6.97 \mathrm{e}-03$ & $3.99 \mathrm{e}+01$ & $2.20 \mathrm{e}+06$ & 0.37 & 198.4 & 0.3 \\
\hline 950 & 0.432 & $5.23 \mathrm{e}-04$ & $2.25 \mathrm{e}-01$ & $4.45 \mathrm{e}-02$ & $4.08 \mathrm{e}+01$ & $7.80 \mathrm{e}+04$ & 0.75 & 202.1 & 0.3 \\
\hline 1000 & 0.508 & $8.55 \mathrm{e}-06$ & $3.29 \mathrm{e}-01$ & $6.69 \mathrm{e}-02$ & $4.07 \mathrm{e}+01$ & $4.76 \mathrm{e}+06$ & 1.09 & 202.3 & 0.4 \\
\hline 1050 & 0.609 & $6.43 \mathrm{e}-06$ & $2.77 \mathrm{e}-01$ & $7.50 \mathrm{e}-02$ & $4.05 \mathrm{e}+01$ & $6.30 \mathrm{e}+06$ & 0.92 & 201.3 & 0.5 \\
\hline 1100 & 0.717 & $6.01 \mathrm{e}-06$ & $2.63 \mathrm{e}-01$ & $6.33 \mathrm{e}-02$ & $4.01 \mathrm{e}+01$ & $6.67 \mathrm{e}+06$ & 0.88 & 199.5 & 0.3 \\
\hline 1150 & 0.831 & $5.90 \mathrm{e}-04$ & $4.65 \mathrm{e}-01$ & $4.71 \mathrm{e}-02$ & $4.03 \mathrm{e}+01$ & $6.82 \mathrm{e}+04$ & 1.55 & 199.6 & 0.3 \\
\hline 1200 & 0.928 & $3.26 \mathrm{e}-04$ & $1.48 \mathrm{e}+00$ & $4.14 \mathrm{e}-02$ & $4.02 \mathrm{e}+01$ & $1.24 \mathrm{e}+05$ & 1.94 & 200.2 & 0.3 \\
\hline 1250 & 0.964 & $1.83 \mathrm{e}-05$ & $4.35 \mathrm{e}+00$ & $2.92 \mathrm{e}-02$ & $4.11 \mathrm{e}+01$ & $2.24 \mathrm{e}+06$ & 14.5 & 204.5 & 0.6 \\
\hline 1300 & 0.976 & $5.09 \mathrm{e}-05$ & $1.20 \mathrm{e}+01$ & $5.09 \mathrm{e}-05$ & $4.20 \mathrm{e}+01$ & $8.26 \mathrm{e}+05$ & 40.2 & 210.0 & 2.7 \\
\hline 1600 & 1.000 & $2.71 \mathrm{e}-05$ & $1.19 \mathrm{e}+01$ & $4.18 \mathrm{e}-02$ & $4.36 \mathrm{e}+01$ & $1.61 \mathrm{e}+06$ & 40.0 & 217.2 & 0.8 \\
\hline
\end{tabular}

Sample mass $=563.2 \mathrm{mg} ; J$-value $=0.002917 \pm 0.000003 ;$ Integrated date $=197.9 \pm 0.2 \mathrm{Ma}{ }^{39} \mathrm{Ar}$ volume $=0.5745 \mathrm{e}-11 \mathrm{ccSTP} / \mathrm{g} ;{ }^{40} \mathrm{Ar} *$ volume $=$ $0.2283 \mathrm{e}-09 \mathrm{ccSTP} / \mathrm{g}) ;$ Plateau age $=200.6 \pm 0.2 \mathrm{Ma}\left(950-1200{ }^{\circ} \mathrm{C} ; 55.2 \%{ }^{39} \mathrm{Ar}\right)$.

Mineral separates ( $>99 \%$ pure) were prepared using conventional heavy liquid and magnetic separation techniques. After sieving, mineral grains in the range of $250-140 \mu \mathrm{m}$ were ultrasonically cleaned in $0.5 \mathrm{~N} \mathrm{HCl}$, washed with distilled water and then dried and handpicked to remove any visible contamination.

The samples were irradiated in the VT-C position at the THOR Reactor in Taiwan for $30 \mathrm{~h}$. In order to monitor the neutron flux in the reactor, two aliquots of the LP-6 Biotite standard were stacked along with the samples in each irradiation. Standards and samples were either incrementally heated or totally fused using a double-vacuum resistance furnace and/or a US LASER Nd-YAG laser operated in continuous mode, and the gas was measured by a VG-3600 mass spectrometer at the National Taiwan University. The $J$-values were calculated using argon compositions of the LP-6 biotite standard with an ${ }^{40} \mathrm{Ar} /{ }^{39} \mathrm{Ar}$ age of 128.4 $\pm 0.2 \mathrm{Ma}$ (Renne et al., 1998). Ages were calculated from Ar isotope ratios measured after corrections made for mass discrimination, interfering nuclear reactions, decay of radiometric isotopes, procedural blanks and atmospheric Ar contamination. Total gas ages were calculated from the sum total of the argon compositions of all the temperature steps. Plateau dates were calculated by the same approach, but utilizing only the adjacent temperature steps yielding dates which are concordant with each other within $2 \sigma$. The ${ }^{39} \mathrm{Ar}_{\mathrm{K}},{ }^{38} \mathrm{Ar}_{\mathrm{Cl}}$ and ${ }^{37} \mathrm{Ar}_{\mathrm{Ca}}$ release data potentially reflect the chemical compositions $(\mathrm{K}, \mathrm{Cl}$ and $\mathrm{Ca}$, respectively) of the samples. $\mathrm{Ca} / \mathrm{K}$ and $\mathrm{Cl} / \mathrm{K}$ ratios were calculated according to the relationships $\mathrm{Ca} / \mathrm{K}=3.319( \pm 0.17) \times{ }^{37} \mathrm{Ar}_{\mathrm{Ca}}{ }^{39} \mathrm{Ar}_{\mathrm{K}}$ and $\mathrm{Cl} / \mathrm{K}=$ $0.22( \pm 0.04) \times{ }^{38} \mathrm{Ar}_{\mathrm{Cl}}{ }^{\beta 9} \mathrm{Ar}_{\mathrm{K}}$, obtained from the analyses of irradiated salts. The analytical results are given in Table 2 and the data are plotted graphically as age spectra in Fig. 3. All errors given in the tables and figures are at $1 \sigma$.

\subsection{Major and trace elements}

After petrographic examination, 24 fresh rock samples were selected, crushed and powdered in an agate mill. Major elements were determined by Xray fluorescence techniques on fused glass beads using Rigaku ${ }^{\circledR}$ RIX-2000 spectrometers at the National Taiwan University. The analytical procedures were the same as those described by Lee et al. (1997) and Wang et al. (2004), yielding analytical uncertainties better than $\pm 5 \%(2 \sigma)$ for all major elements. The fused glass beads were powdered and dissolved using an $\mathrm{HF} / \mathrm{HNO}_{3}(1: 1)$ mixture in screwtop Teflon beakers for $>2 \mathrm{~h}$ at $\sim 100{ }^{\circ} \mathrm{C}$, followed by evaporation to dryness, then refluxing in $7 \mathrm{~N} \mathrm{HNO}_{3}$ for $>12 \mathrm{~h}$ at $\sim 100{ }^{\circ} \mathrm{C}$ and, finally, diluting the sample 
solution by $2 \% \mathrm{HNO}_{3}$. An internal standard solution of $5 \mathrm{ppb} \mathrm{Rh}$ and $\mathrm{Bi}$ was added and the spiked solution was diluted with $2 \% \mathrm{HNO}_{3}$ to a sample/solution weight ratio of 1:2000. An internal standard was used for monitoring the signal shift during inductively coupled plasma-mass spectrometry (ICP-MS) measurements using an Agilent 7500s spectrometer at the National Taiwan University; it shows a good stability range with $\sim 10 \%$ variation. The precision was generally better than $\pm 5 \%(2 \sigma)$ for most trace elements, as shown by the statistics of duplicate analyses on five rock standards AGV-1, AGV-2, GSP-1, JB-1 and JG-1 (see Appendix Table A).

\subsection{Sr and Nd isotopes}

Samples for isotopic analysis were dissolved in Teflon bombs after being spiked with ${ }^{84} \mathrm{Sr},{ }^{87} \mathrm{Rb}$, ${ }^{150} \mathrm{Nd}$ and ${ }^{147} \mathrm{Sm}$ tracers prior to $\mathrm{HF}+\mathrm{HNO}_{3}$ (with a ratio of 2:1) dissolution. Rubidium, $\mathrm{Sr}, \mathrm{Sm}$ and $\mathrm{Nd}$ were separated using conventional ion exchange procedures and measured using a Finnigan MAT 262 multi-collector mass spectrometer at the Institute of Geology and Geophysics, Chinese Academy of Sciences, China. Procedural blanks were $<100 \mathrm{pg}$ for $\mathrm{Sm}$ and $\mathrm{Nd}$ and $<500 \mathrm{pg}$ for $\mathrm{Rb}$ and $\mathrm{Sr} .{ }^{143} \mathrm{Nd} /{ }^{144} \mathrm{Nd}$ were corrected for mass fractionation by normalization to ${ }^{146} \mathrm{Nd} /{ }^{144} \mathrm{Nd}=0.7219$ and ${ }^{87} \mathrm{Sr} /{ }^{86} \mathrm{Sr}$ ratios normalized to ${ }^{86} \mathrm{Sr} /{ }^{88} \mathrm{Sr}=0.1194$. Typical within-run precision $(2 \sigma)$ for $\mathrm{Sr}$ and $\mathrm{Nd}$ was estimated to be \pm 0.000015 . The measured values for the La Jolla and BCR-1 Nd standards and the NBS-607 Sr standard were ${ }^{143} \mathrm{Nd} /{ }^{144} \mathrm{Nd}=0.511853 \pm 7 \quad\left(2 \sigma_{n}, n=3\right)$ and $0.512604 \pm 7 \quad\left(2 \sigma_{n}, n=3\right)$ and ${ }^{87} \mathrm{Sr} /{ }^{86} \mathrm{Sr}=$ $1.20042 \pm 2\left(2 \sigma_{n}, n=12\right)$ during the period of data acquisition.

\section{Results}

\subsection{Geochronology}

SHRIMP U-Pb dating of zircon from the quartz syenite (JZS-3) defines a weighted mean ${ }^{206} \mathrm{~Pb} /{ }^{238} \mathrm{U}$ age of $215 \pm 5 \mathrm{Ma}$ (Fig. 2). A K-feldspar sample from the trachytoid pyroxene syenite (sample JZS11) was dated by the ${ }^{40} \mathrm{Ar} /{ }^{39} \mathrm{Ar}$ method and yields a plateau age of $214.4 \pm 0.3 \mathrm{Ma}$ at high temperature

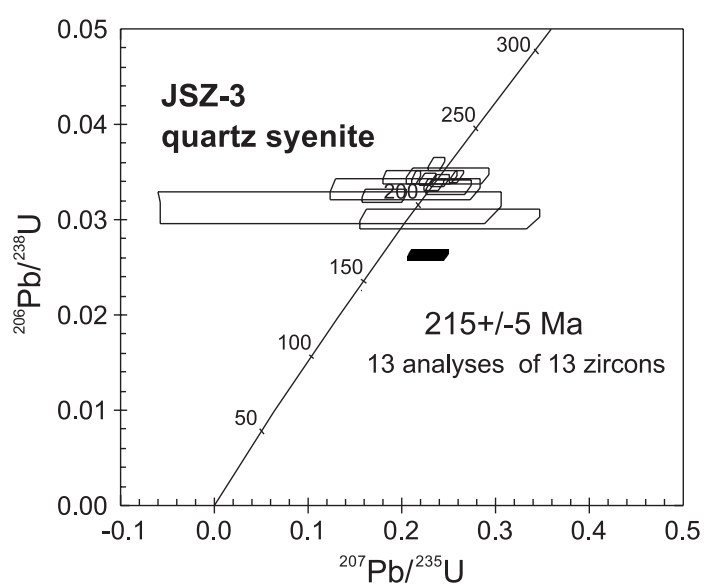

Fig. 2. SHRIMP U-Pb zircon concordia diagram for quartz syenite (JZS-3) from the Jiazishan Complex.

(Fig. 3a). A hornblende sample from porphyritic pyroxene syenite sample JZS-13 gives a plateau age of $214.6 \pm 0.6 \mathrm{Ma}$, composed of the steps with indistinguishable $\mathrm{Ca} / \mathrm{K}$ ratio $(22.56 \pm 0.44$, Fig. $3 b)$. These ages are consistent with the earlier $\mathrm{Rb}-\mathrm{Sr}$ results of $220 \pm 13 \mathrm{Ma}$ (Lin et al., 1992) and zircon $\mathrm{U}-\mathrm{Pb}$ TIMS ages of $225 \pm 2 \mathrm{Ma}$ and $211 \pm 3 \mathrm{Ma}$ for pyroxene and quartz syenite, respectively (Chen et

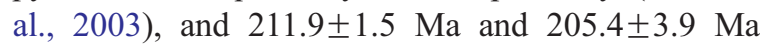
for pyroxene syenites (Guo et al., 2001b). Our new data indicate that the emplacement age of the syenites ranges from 215 to $209 \mathrm{Ma}$. The whole rock sample of ultrapotassic mafic dike defines an ${ }^{40} \mathrm{Ar} /{ }^{39} \mathrm{Ar}$ plateau age of $200.6 \pm 0.2 \mathrm{Ma}$ (Fig. 3c), constraining the emplacement age of the mafic dike. All these ages post-date the orogenic and UHP metamorphic ages of coesite-bearing eclogites in the Dabie-Sulu orogeny (240-220 Ma; Ames et al., 1993; Li et al., 1993a,b; Chavagnac and Jahn, 1996; Hacker et al., 1998; Webb et al., 1999; Zheng et al., 2002; Liu et al., 2004).

\subsection{Geochemical characteristics}

The geochemical and isotopic data for the syenites and mafic dike from the Jiazishan Complex are listed in Tables 3 and 4.

The Jiazishan syenites show a range in $\mathrm{SiO}_{2}$ values from 54.44 to $64.20 \mathrm{wt} \%$. Nepheline-normative pyroxene syenites, mafic enclaves and the mafic dike represent a silica-undersaturated suite of rocks, 

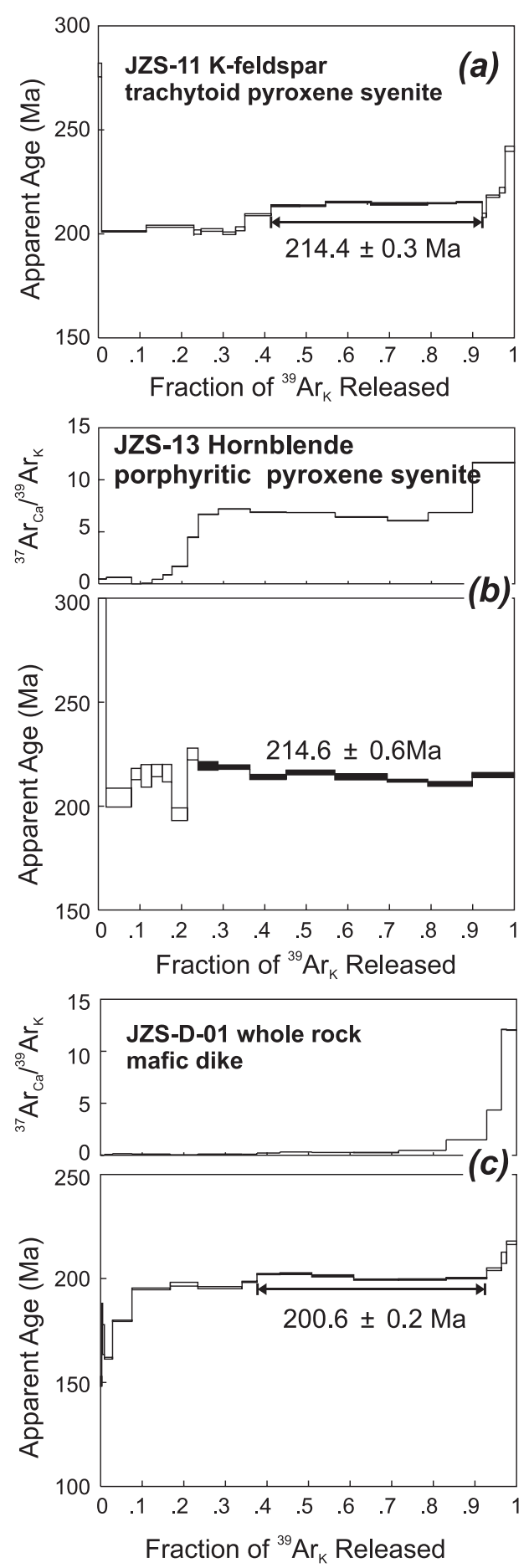

Fig. 3. ${ }^{40} \mathrm{Ar} /{ }^{39} \mathrm{Ar}$ age spectra of (a) K-feldspar from pyroxene syenite sample JZS-11, (b) hornblende from pyroxene syenite sample JZS-13 and (c) whole rock mafic dike (JZS-D-01). whereas the quartz syenites have normative quartz and are silica-saturated.

All samples plot in the alkaline field on the total alkali-silica (TAS) diagram (Fig. 4a). Three samples of mafic dike plot in the potassic trachybasalt field with $>10 \%$ normative olivine (Table 3 ), whereas the other sample plots in the shoshonite field with $\mathrm{Na}_{2} \mathrm{O}-2<\mathrm{K}_{2} \mathrm{O}$ (Table 3). Pyroxene syenite samples plot in the latite and trachyte fields and quartz syenite plots in the trachyte field. One mafic enclave sample plots in the phonotephrite field and the other sample plots in the latite field (Fig. 4a). In the $\mathrm{Na}_{2} \mathrm{O}$ vs. $\mathrm{K}_{2} \mathrm{O}$ plot (Fig. $4 b$ ), pyroxene and quartz syenites belong to the shoshonitic series, whereas the mafic dike samples, having $\mathrm{K}_{2} \mathrm{O}>3$ wt. $\%, \mathrm{~K}_{2} \mathrm{O} / \mathrm{Na}_{2} \mathrm{O}>2, \mathrm{MgO}>3$ wt. $\%$ and high $\mathrm{Cr}$ (477-873 ppm), are ultrapotassic rocks as defined by Foley et al. (1987).

Fig. $4 \mathrm{c}$ shows the composition of the syenites and mafic dikes in terms of their molar ratios of $\mathrm{Al}_{2} \mathrm{O}_{3}$ / $\left(\mathrm{CaO}+\mathrm{Na}_{2} \mathrm{O}+\mathrm{K}_{2} \mathrm{O}\right)(\mathrm{A} / \mathrm{CNK})$ and $\mathrm{Al}_{2} \mathrm{O}_{3} /\left(\mathrm{Na}_{2} \mathrm{O}+\mathrm{K}_{2} \mathrm{O}\right)$ (A/NK). Based on these ratios, the pyroxene syenite and mafic dikes are metaluminous, whereas the quartz syenites straddle the metaluminous-peraluminous boundary. All rocks of the Jiazishan Complex display regular trends of increasing $\mathrm{Al}_{2} \mathrm{O}_{3}, \mathrm{SiO}_{2}, \mathrm{Na}_{2} \mathrm{O}, \mathrm{K}_{2} \mathrm{O}$ and decreasing $\mathrm{CaO}, \mathrm{Fe}_{2} \mathrm{O}_{3}, \mathrm{TiO}_{2}, \mathrm{P}_{2} \mathrm{O}_{5}, \mathrm{~V}, \mathrm{Cr}$ and $\mathrm{Ni}$ with decreasing $\mathrm{MgO}$ (Figs. 5 and 6). Pyroxene syenites and mafic enclaves have high $\mathrm{Sr}, \mathrm{Ba}$ and $\mathrm{Rb}$, whereas quartz syenites have low $\mathrm{Sr}$ and $\mathrm{Ba}$ contents (Fig. 6d-f). The mafic dikes always have a separate trend (Figs. 5 and 6), indicating that they are not comagmatic with the syenites.

The more siliceous rocks of the Jiazishan Complex (quartz syenite, $\mathrm{SiO}_{2}>60$ wt.\%) display characteristics of A-type magmas as defined by Eby (1990), exhibiting anhydrous, hypersolvus mineralogy and an alkaline chemical affinity with low $\mathrm{CaO}$ (1.15-1.43 wt.\%) and $\mathrm{Sr}$ and $\mathrm{Ba}$ concentrations (Table 3) and high Ga concentrations ( $>20 \mathrm{ppm}$ ). High concentrations of $\mathrm{Zr}, \mathrm{Nb}, \mathrm{Ce}$ and $\mathrm{Y}$ distinguish the Jiazishan quartz syenites from I- and Stype granites and classify them as an A-type granite on the $10000 \mathrm{Ga} / \mathrm{Al}$ vs. $\mathrm{Zr}$ and $\mathrm{Na}_{2} \mathrm{O}+\mathrm{K}_{2} \mathrm{O}$ discrimination diagrams (Fig. 7a and b) of Whalen et al. (1987).

The chondrite-normalized REE patterns of the pyroxene syenites (Fig. 8a) show LREE enrichment, 
Table 3

Chemical compositions of rocks from the Jiazishan Complex

\begin{tabular}{|c|c|c|c|c|c|c|c|c|c|c|c|c|c|c|c|c|c|c|c|c|c|c|c|}
\hline No. & JZS-01 & JZS0-02 & JZS-03 & JZS-04 & JZS-05 & JZS-06 & JZS-07-1 & JZS-07-2 & JZS-08-1 & JZS-08-2 & JZS-09 & JZS-10 & JZS-11 & JZS-12 & JZS-13 & JZS-14 & JZS-15 & JZS-16 & JZS-17 & JZS-D-2 & JZS-D-3 & JZS-D-4 & JZS-D-5 \\
\hline Rock & \multicolumn{6}{|c|}{ Quartz syenite } & Enclave & Py syenite & Enclave & Pyroxene & syenite & & \multicolumn{2}{|c|}{ Pyroxene syenite } & \multicolumn{5}{|c|}{ Pyroxene syenite } & \multicolumn{4}{|c|}{ Mafic dike } \\
\hline $\begin{array}{l}\text { Longitude } \\
\text { and latitude }\end{array}$ & \multicolumn{6}{|c|}{ E122 $24^{\prime} 10.7^{\prime \prime}, \mathrm{N} 36^{\circ} 54^{\prime 22.6^{\prime \prime}}$} & \multicolumn{6}{|c|}{ 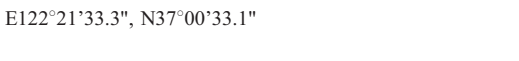 } & \multicolumn{2}{|c|}{$\begin{array}{l}\text { E122 } 26^{\prime} 16.9^{\prime \prime} \\
\text { N37 }\end{array}$} & \multicolumn{5}{|c|}{ E122 $27^{\circ} 06.4^{\prime \prime}$, N36 $58^{\circ} 05.5^{\prime \prime}$} & \multicolumn{4}{|c|}{ E122 $27^{\prime} 06.4^{\prime \prime}$, N36 $58^{\circ} 05.5^{\prime \prime}$} \\
\hline \multicolumn{24}{|c|}{ Major element (in wt.\%) } \\
\hline $\mathrm{SiO}_{2}$ & 63.57 & 63.70 & 64.03 & 64.01 & 64.20 & 63.13 & 53.45 & 60.10 & 48.09 & 60.06 & 59.72 & 60.11 & 59.31 & 58.47 & 54.44 & 56.59 & 56.29 & 55.86 & 56.67 & 48.05 & 48.27 & 46.60 & 50.81 \\
\hline $\mathrm{TiO}_{2}$ & 0.32 & 0.34 & 0.33 & 0.33 & 0.30 & 0.39 & 0.84 & 0.52 & 1.20 & 0.52 & 0.52 & 0.52 & 0.53 & 0.70 & 1.00 & 0.64 & 0.69 & 0.80 & 0.80 & 1.16 & 1.16 & 1.12 & 1.32 \\
\hline $\mathrm{Al}_{2} \mathrm{O}_{3}$ & 18.45 & 18.49 & 18.53 & 18.56 & 18.72 & 18.23 & 17.00 & 18.29 & 16.82 & 17.80 & 18.13 & 18.13 & 18.09 & 17.79 & 15.22 & 16.98 & 17.15 & 16.36 & 17.67 & 12.44 & 11.51 & 11.10 & 12.43 \\
\hline $\mathrm{Fe}_{2} \mathrm{O}_{3}$ & 2.37 & 2.34 & 2.28 & 2.37 & 2.03 & 2.87 & 7.54 & 3.84 & 10.20 & 3.88 & 3.97 & 3.82 & 4.09 & 4.49 & 7.27 & 5.56 & 5.62 & 5.87 & 5.15 & 8.84 & 8.90 & 8.60 & 7.33 \\
\hline $\mathrm{MnO}$ & 0.11 & 0.10 & 0.10 & 0.11 & 0.08 & 0.13 & 0.16 & 0.10 & 0.16 & 0.10 & 0.11 & 0.10 & 0.10 & 0.10 & 0.15 & 0.11 & 0.13 & 0.14 & 0.10 & 0.13 & 0.14 & 0.13 & 0.11 \\
\hline $\mathrm{MgO}$ & 0.35 & 0.24 & 0.28 & 0.32 & 0.20 & 0.41 & 3.07 & 1.36 & 4.80 & 1.44 & 1.40 & 1.33 & 1.49 & 1.17 & 3.56 & 2.36 & 2.52 & 3.22 & 2.36 & 10.04 & 12.44 & 11.97 & 8.06 \\
\hline $\mathrm{CaO}$ & 1.37 & 1.27 & 1.31 & 1.34 & 1.15 & 1.43 & 5.90 & 3.06 & 6.74 & 3.14 & 3.13 & 3.03 & 3.38 & 2.74 & 5.44 & 4.21 & 4.20 & 4.93 & 3.91 & 8.24 & 8.78 & 8.47 & 6.88 \\
\hline $\mathrm{Na}_{2} \mathrm{O}$ & 5.23 & 5.23 & 5.23 & 5.31 & 5.33 & 5.14 & 4.02 & 4.27 & 3.19 & 3.65 & 4.22 & 4.30 & 4.29 & 3.84 & 3.49 & 3.93 & 3.96 & 3.69 & 3.83 & 1.56 & 1.37 & 1.42 & 1.85 \\
\hline $\mathrm{K}_{2} \mathrm{O}$ & 6.82 & 6.94 & 6.94 & 6.75 & 7.05 & 6.97 & 4.59 & 7.04 & 4.23 & 7.57 & 6.89 & 6.99 & 6.76 & 7.88 & 6.04 & 6.53 & 6.64 & 6.40 & 6.83 & 5.39 & 4.41 & 4.98 & 6.40 \\
\hline $\mathrm{P}_{2} \mathrm{O}_{5}$ & 0.09 & 0.07 & 0.07 & 0.08 & 0.06 & 0.10 & 0.81 & 0.33 & 1.26 & 0.35 & 0.33 & 0.32 & 0.35 & 0.24 & 0.73 & 0.54 & 0.52 & 0.59 & 0.51 & 0.99 & 0.96 & 0.93 & 0.97 \\
\hline TOTAL & 98.68 & 98.71 & 99.10 & 99.17 & 99.11 & 98.78 & 97.38 & 98.90 & 96.69 & 98.50 & 98.42 & 98.65 & 98.39 & 97.41 & 97.33 & 97.46 & 97.72 & 97.86 & 97.82 & 96.84 & 97.94 & 95.32 & 96.14 \\
\hline Mg\# & 22.40 & 16.83 & 19.33 & 21.08 & 16.16 & 21.90 & 44.68 & 41.21 & 48.23 & 42.35 & 41.14 & 40.84 & 41.86 & 34.14 & 49.24 & 45.70 & 47.08 & 52.07 & 47.64 & 69.22 & 73.46 & 73.40 & 68.53 \\
\hline $\mathrm{A} / \mathrm{CNK}$ & 1.00 & 1.00 & 1.00 & 1.01 & 1.01 & 0.98 & 0.76 & 0.91 & 0.76 & 0.89 & 0.90 & 0.90 & 0.88 & 0.90 & 0.69 & 0.80 & 0.80 & 0.74 & 0.85 & 0.53 & 0.50 & 0.48 & 0.55 \\
\hline $\mathrm{A} / \mathrm{NK}$ & 1.15 & 1.15 & 1.15 & 1.16 & 1.14 & 1.14 & 1.47 & 1.25 & 1.71 & 1.25 & 1.26 & 1.24 & 1.26 & 1.20 & 1.24 & 1.25 & 1.25 & 1.26 & 1.29 & 1.48 & 1.64 & 1.44 & 1.25 \\
\hline \multicolumn{24}{|c|}{ CIPW normative minerals (\%) } \\
\hline$Q$ & 3.84 & 3.83 & 4.02 & 4.16 & 3.62 & 3.24 & & 1.03 & & 2.38 & 1.22 & 1.22 & 0.47 & & & & & & & & & & \\
\hline $\mathrm{Ne}$ & & & & & & & 0.50 & & 2.82 & & & & & & 0.84 & 0.42 & 1.63 & 0.99 & 0.31 & 3.45 & 0.85 & 4.34 & 1.06 \\
\hline \multicolumn{24}{|c|}{ Trace elements (in ppm) } \\
\hline $\mathrm{V}$ & 32.6 & 30.5 & 29.6 & 31.4 & 26.7 & 29.1 & 162 & 76.3 & 185 & 72.4 & 76.2 & 70.0 & 79.1 & 76.8 & 126 & 103 & 104 & 98.7 & 104 & 172 & 166 & 154 & 133 \\
\hline $\mathrm{Cr}$ & 2.80 & 4.47 & 3.16 & 2.96 & 2.42 & 2.05 & 6.09 & 10.3 & 36.9 & 7.74 & 9.56 & 15.2 & 12.3 & 11.6 & 63.1 & 18.8 & 19.5 & 51.2 & 14.9 & 630 & 873 & 834 & 477 \\
\hline Сo & 1.41 & 1.28 & 1.31 & 1.48 & 1.16 & 1.40 & 22.9 & 8.17 & 28.8 & 7.31 & 8.75 & 8.32 & 9.25 & 8.60 & 20.4 & 14.0 & 15.9 & 19.1 & 14.8 & 39.7 & 45.1 & 42.2 & 30.5 \\
\hline
\end{tabular}




\begin{tabular}{|c|c|c|c|c|c|c|c|c|c|c|c|c|c|c|c|c|c|c|c|c|c|c|c|}
\hline $\mathrm{Ni}$ & 1.81 & 2.77 & 1.79 & 1.73 & 1.63 & 1.65 & 13.6 & 6.38 & 18.4 & 6.78 & 8.13 & 9.14 & 7.76 & 8.55 & 18.2 & 12.6 & 15.0 & 15.2 & 12.9 & 224 & 319 & 300 & 119 \\
\hline $\mathrm{Cu}$ & 5.30 & 3.92 & 4.56 & 4.23 & 3.91 & 3.95 & 47.0 & 6.41 & 27.3 & 21.4 & 7.47 & 10.2 & 9.98 & 14.8 & 15.3 & 10.5 & 12.4 & 39.6 & 18.3 & 45.9 & 58.8 & 57.4 & 133 \\
\hline $\mathrm{Zn}$ & 57.5 & 47.5 & 50.0 & 53.9 & 44.5 & 58.0 & 132 & 65.0 & 141 & 68.6 & 64.7 & 67.8 & 80.0 & 69.9 & 84.8 & 64.4 & 67.3 & 81.0 & 68.4 & 81.2 & 77.1 & 72.0 & 108 \\
\hline Ga & 21.9 & 21.5 & 21.8 & 21.8 & 21.6 & 22.0 & 21.4 & 20.0 & 20.4 & 19.5 & 20.3 & 20.0 & 20.3 & 22.2 & 23.3 & 21.3 & 21.3 & 22.1 & 20.2 & 16.0 & 14.9 & 14.3 & 16.4 \\
\hline $\mathrm{Rb}$ & 145 & 146 & 150 & 138 & 147 & 145 & 126 & 162 & 113 & 159 & 155 & 155 & 153 & 179 & 184 & 179 & 196 & 193 & 179 & 113 & 86.4 & 102 & 161 \\
\hline $\mathrm{Sr}$ & 221 & 205 & 192 & 191 & 217 & 213 & 2352 & 1323 & 3832 & 1409 & 1319 & 1213 & 1411 & 1053 & 1411 & 1790 & 2002 & 1511 & 2064 & 1649 & 1484 & 1413 & 1644 \\
\hline Y & 44.0 & 50.4 & 47.0 & 47.0 & 43.4 & 53.7 & 37.1 & 25.9 & 30.5 & 28.2 & 25.4 & 23.7 & 24.7 & 49.0 & 45.5 & 29.1 & 27.4 & 35.7 & 32.2 & 24.2 & 23.3 & 22.2 & 20.8 \\
\hline $\mathrm{Zr}$ & 699 & 635 & 675 & 680 & 557 & 848 & 514 & 651 & 276 & 588 & 685 & 621 & 631 & 1422 & 973 & 654 & 613 & 543 & 123 & 458 & 526 & 498 & 622 \\
\hline $\mathrm{Nb}$ & 28.5 & 31.9 & 30.5 & 30.5 & 27.2 & 34.7 & 32.2 & 9.62 & 9.75 & 17.6 & 10.7 & 10.2 & 9.6 & 50.4 & 64.4 & 30.0 & 24.6 & 43.9 & 37.5 & 12.8 & 14.6 & 13.9 & 16.6 \\
\hline Cs & 1.35 & 1.43 & 1.43 & 0.96 & 1.16 & 1.14 & 2.55 & 2.12 & 3.85 & 2.88 & 1.94 & 1.93 & 2.23 & 1.85 & 9.34 & 4.73 & 5.70 & 6.37 & 4.86 & 2.55 & 2.29 & 3.19 & 2.42 \\
\hline $\mathrm{Ba}$ & 469 & 597 & 462 & 425 & 437 & 508 & 103700 & 4142 & 102000 & 4287 & 3914 & 3814 & 3939 & 2769 & 3448 & 5031 & 5689 & 3863 & 56230 & 5167 & 4763 & 4628 & 4254 \\
\hline $\mathrm{La}$ & 168.4 & 135.5 & 133.8 & 147.9 & 135.1 & 164.4 & 150.4 & 97.20 & 129.1 & 100.6 & 89.95 & 79.66 & 84.27 & 194.7 & 147.1 & 118.0 & 115.8 & 132.9 & 137.6 & 78.75 & 65.68 & 62.94 & 62.02 \\
\hline $\mathrm{Ce}$ & 322.9 & 280.9 & 266.4 & 282.0 & 256.9 & 320.1 & 282.5 & 174.3 & 248.7 & 188.1 & 167.4 & 148.7 & 157.2 & 389.6 & 306.0 & 220.0 & 210.6 & 258.1 & 272.5 & 157.9 & 136.7 & 130.8 & 125.0 \\
\hline $\operatorname{Pr}$ & 33.60 & 31.56 & 29.03 & 29.52 & 27.09 & 33.86 & 30.17 & 18.95 & 28.43 & 20.27 & 18.05 & 16.08 & 17.12 & 41.67 & 33.41 & 22.85 & 21.92 & 27.27 & 29.16 & 19.35 & 16.96 & 16.12 & 15.21 \\
\hline $\mathrm{Nd}$ & 121.1 & 120.2 & 108.0 & 106.6 & 97.17 & 124.3 & 113.3 & 72.51 & 116.8 & 77.23 & 69.24 & 62.50 & 66.68 & 152.7 & 126.1 & 84.32 & 81.68 & 101.5 & 109.6 & 75.83 & 66.46 & 63.43 & 58.82 \\
\hline $\mathrm{Sm}$ & 17.77 & 20.29 & 17.42 & 16.28 & 14.88 & 18.96 & 16.49 & 10.67 & 17.46 & 11.45 & 10.42 & 9.53 & 10.13 & 21.80 & 18.86 & 12.27 & 11.87 & 14.98 & 16.45 & 12.82 & 11.69 & 11.00 & 10.03 \\
\hline Eu & 2.31 & 2.25 & 2.01 & 1.94 & 1.69 & 2.19 & 4.45 & 2.96 & 5.36 & 2.93 & 2.82 & 2.69 & 2.83 & 3.50 & 3.61 & 3.05 & 3.17 & 3.05 & 3.99 & 4.06 & 3.54 & 3.31 & 3.15 \\
\hline Gd & 13.86 & 15.32 & 13.25 & 12.83 & 11.72 & 14.44 & 12.65 & 8.24 & 13.13 & 8.76 & 7.94 & 7.15 & 7.71 & 16.09 & 14.09 & 9.42 & 9.11 & 11.22 & 11.78 & 9.82 & 8.85 & 8.22 & 7.56 \\
\hline $\mathrm{Tb}$ & 1.85 & 2.24 & 1.86 & 1.74 & 1.63 & 1.98 & 1.52 & 1.03 & 1.50 & 1.10 & 1.00 & 0.92 & 0.98 & 2.04 & 1.78 & 1.14 & 1.11 & 1.41 & 1.45 & 1.08 & 1.00 & 0.94 & 0.86 \\
\hline Dy & 8.60 & 10.89 & 8.98 & 8.28 & 7.71 & 9.37 & 6.50 & 4.64 & 6.15 & 4.88 & 4.46 & 4.12 & 4.37 & 8.87 & 7.95 & 5.04 & 4.76 & 6.21 & 6.21 & 4.62 & 4.44 & 4.19 & 3.85 \\
\hline Ho & 1.55 & 1.99 & 1.64 & 1.52 & 1.42 & 1.72 & 1.17 & 0.82 & 1.03 & 0.89 & 0.81 & 0.74 & 0.79 & 1.57 & 1.41 & 0.89 & 0.85 & 1.09 & 1.05 & 0.87 & 0.83 & 0.78 & 0.73 \\
\hline Er & 4.59 & 5.71 & 4.69 & 4.48 & 4.09 & 5.05 & 3.38 & 2.43 & 2.75 & 2.57 & 2.35 & 2.17 & 2.28 & 4.67 & 4.10 & 2.63 & 2.45 & 3.17 & 2.98 & 2.24 & 2.15 & 2.02 & 1.92 \\
\hline $\mathrm{Tm}$ & 0.69 & 0.84 & 0.71 & 0.66 & 0.61 & 0.74 & 0.50 & 0.35 & 0.36 & 0.39 & 0.34 & 0.32 & 0.33 & 0.70 & 0.63 & 0.40 & 0.36 & 0.49 & 0.43 & 0.27 & 0.26 & 0.25 & 0.24 \\
\hline $\mathrm{Yb}$ & 4.31 & 5.07 & 4.41 & 4.07 & 3.58 & 4.72 & 3.21 & 2.22 & 2.18 & 2.47 & 2.22 & 2.04 & 2.12 & 4.47 & 4.05 & 2.63 & 2.33 & 3.12 & 2.64 & 1.70 & 1.71 & 1.58 & 1.54 \\
\hline Lu & 0.63 & 0.72 & 0.62 & 0.58 & 0.51 & 0.68 & 0.49 & 0.34 & 0.32 & 0.38 & 0.34 & 0.32 & 0.33 & 0.69 & 0.62 & 0.41 & 0.35 & 0.47 & 0.37 & 0.25 & 0.24 & 0.23 & 0.22 \\
\hline $\mathrm{Hf}$ & 18.4 & 19.8 & 18.1 & 16.8 & 14.5 & 20.0 & 12.6 & 14.8 & 6.3 & 13.1 & 14.9 & 13.5 & 13.6 & 31.4 & 23.0 & 15.1 & 13.7 & 13.2 & 4.03 & 10.1 & 11.5 & 10.9 & 14.8 \\
\hline Ta & 2.42 & 3.05 & 2.58 & 2.42 & 2.17 & 2.66 & 2.14 & 0.62 & 0.61 & 1.44 & 0.64 & 0.62 & 0.56 & 5.54 & 5.33 & 1.64 & 1.58 & 3.13 & 2.71 & 0.61 & 0.70 & 0.66 & 0.74 \\
\hline $\mathrm{Pb}$ & 54.4 & 54.6 & 164 & 59.3 & 81.6 & 64.5 & 113 & 81.1 & 78.2 & 80.9 & 71.0 & 298 & 99.1 & 219 & 79.2 & 68.1 & 58.0 & 73.6 & 74.1 & 28.8 & 30.4 & 31.1 & 26.4 \\
\hline Th & 24.2 & 21.8 & 21.4 & 22.0 & 22.2 & 26.2 & 46.5 & 10.5 & 5.72 & 17.6 & 10.5 & 9.00 & 8.42 & 47.6 & 49.7 & 28.4 & 28.4 & 59.8 & 26.4 & 8.82 & 9.24 & 8.99 & 5.81 \\
\hline $\mathrm{U}$ & 2.58 & 2.76 & 2.99 & 2.91 & 1.98 & 2.73 & 7.33 & 1.98 & 1.44 & 5.36 & 1.94 & 1.97 & 2.07 & 5.06 & 15.2 & 6.02 & 7.27 & 9.02 & 5.09 & 1.68 & 1.80 & 1.73 & 1.21 \\
\hline
\end{tabular}


Table 4

$\mathrm{Sr}$ and $\mathrm{Nd}$ isotopic compositions of rocks from the Jiazishan Complex

\begin{tabular}{|c|c|c|c|c|c|c|c|c|c|c|c|c|c|c|c|}
\hline Sample no. & Rock type & $\mathrm{Rb}$ (ppm) & $\mathrm{Sr}(\mathrm{ppm})$ & ${ }^{87} \mathrm{Rb} /{ }^{86} \mathrm{Sr}$ & ${ }^{87} \mathrm{Sr} /{ }^{86} \mathrm{Sr}$ & $2 \sigma$ & Sm (ppm) & $\mathrm{Nd}(\mathrm{ppm})$ & ${ }^{147} \mathrm{Sm} /{ }^{144} \mathrm{Nd}$ & ${ }^{143} \mathrm{Nd} /{ }^{144} \mathrm{Nd}$ & $2 \sigma$ & ${ }^{87} \mathrm{Sr} /{ }^{86} \mathrm{Sr}_{i}$ & $\varepsilon_{\mathrm{Nd}}(t)^{\mathrm{a}}$ & $T_{\mathrm{DM}}(\mathrm{Ma})^{\mathrm{b}}$ & $f_{\mathrm{Sm} / \mathrm{Nd}}$ \\
\hline JZS-01 & Qz syenite & 138 & 221 & 1.805 & 0.712435 & 11 & 17.7 & 122 & 0.0882 & 0.511688 & 11 & 0.70692 & -15.6 & 1771 & -0.55 \\
\hline JZS-02 & Qz syenite & 138 & 205 & 1.947 & 0.713034 & 8 & 18.6 & 112 & 0.1000 & 0.511702 & 5 & 0.70708 & -15.6 & 1934 & -0.49 \\
\hline JZS-03 & Qz syenite & 141 & 195 & 2.090 & 0.713454 & 11 & 17.8 & 113 & 0.0952 & 0.511665 & 12 & 0.70706 & -16.2 & 1904 & -0.52 \\
\hline JZS-04 & Qz syenite & 132 & 195 & 1.966 & 0.712971 & 16 & 17.9 & 120 & 0.0907 & 0.511680 & 9 & 0.70696 & -15.8 & 1817 & -0.54 \\
\hline JZS-07-1 & Mafic enclave & 120 & 2352 & 0.1480 & 0.706891 & 11 & 18.0 & 126 & 0.0862 & 0.511733 & 7 & 0.70644 & -14.6 & 1690 & -0.56 \\
\hline JZS-08-1 & Mafic enclave & 112 & 3814 & 0.0853 & 0.706844 & 7 & 20.2 & 137 & 0.0890 & 0.511730 & 7 & 0.70658 & -14.8 & 1732 & -0.55 \\
\hline JZS-09 & Py syenite & 153 & 1215 & 0.3634 & 0.707840 & 14 & 11.7 & 80.3 & 0.0882 & 0.511687 & 6 & 0.70673 & -15.6 & 1773 & -0.55 \\
\hline JZS-10 & Py syenite & 153 & 1213 & 0.3638 & 0.707799 & 11 & 11.0 & 73.6 & 0.0900 & 0.511684 & 10 & 0.70669 & -15.7 & 1801 & -0.54 \\
\hline JZS-11 & Py syenite & 145 & 1294 & 0.3245 & 0.707695 & 8 & 11.4 & 77.0 & 0.0898 & 0.511709 & 7 & 0.70670 & -15.2 & 1769 & -0.54 \\
\hline JZS-12 & Py syenite & 173 & 1053 & 0.4745 & 0.708044 & 12 & 25.1 & 179 & 0.0852 & 0.511689 & 8 & 0.70659 & -15.5 & 1728 & -0.57 \\
\hline JZS-13 & Py syenite & 184 & 1339 & 0.3981 & 0.708026 & 10 & 22.3 & 151 & 0.0892 & 0.511710 & 6 & 0.70681 & -15.2 & 1759 & -0.55 \\
\hline JZS-14 & Py syenite & 182 & 1705 & 0.3091 & 0.707743 & 9 & 14.2 & 99.5 & 0.0862 & 0.511703 & 5 & 0.70680 & -15.2 & 1726 & -0.56 \\
\hline JZS-15 & Py syenite & 186 & 1837 & 0.2930 & 0.707711 & 8 & 13.6 & 94.7 & 0.0867 & 0.511673 & 12 & 0.70682 & -15.8 & 1769 & -0.56 \\
\hline JZS-16 & Py syenite & 187 & 1409 & 0.3840 & 0.708038 & 7 & 17.5 & 121 & 0.0876 & 0.511692 & 10 & 0.70686 & -15.5 & 1758 & -0.55 \\
\hline JZS-D-2 & Mafic dike & 110 & 1668 & 0.1908 & 0.707801 & 13 & 13.2 & 81.3 & 0.0981 & 0.511656 & 9 & 0.70722 & -16.5 & 1963 & -0.50 \\
\hline JZS-D-3 & Mafic dike & 102 & 1529 & 0.1923 & 0.707872 & 8 & 12.0 & 72.3 & 0.1007 & 0.511660 & 4 & 0.70728 & -16.4 & 2003 & -0.49 \\
\hline JZS-D-4 & Mafic dike & & & & & & 5.97 & 36.2 & 0.0999 & 0.511655 & 6 & & -16.5 & 1996 & -0.49 \\
\hline
\end{tabular}

a and b: The ${ }^{143} \mathrm{Nd} /{ }^{144} \mathrm{Nd}$ and ${ }^{147} \mathrm{Sm} /{ }^{144} \mathrm{Nd}$ of chondrite and depleted mantle at present day are 0.512638 and $0.1967,0.51315$ and 0.222 , respectively.

${ }^{87} \mathrm{Sr}^{86} \mathrm{Sr}_{i}$ and $\varepsilon_{\mathrm{Nd}}(t)$ were calculated at $215 \mathrm{Ma}$. 

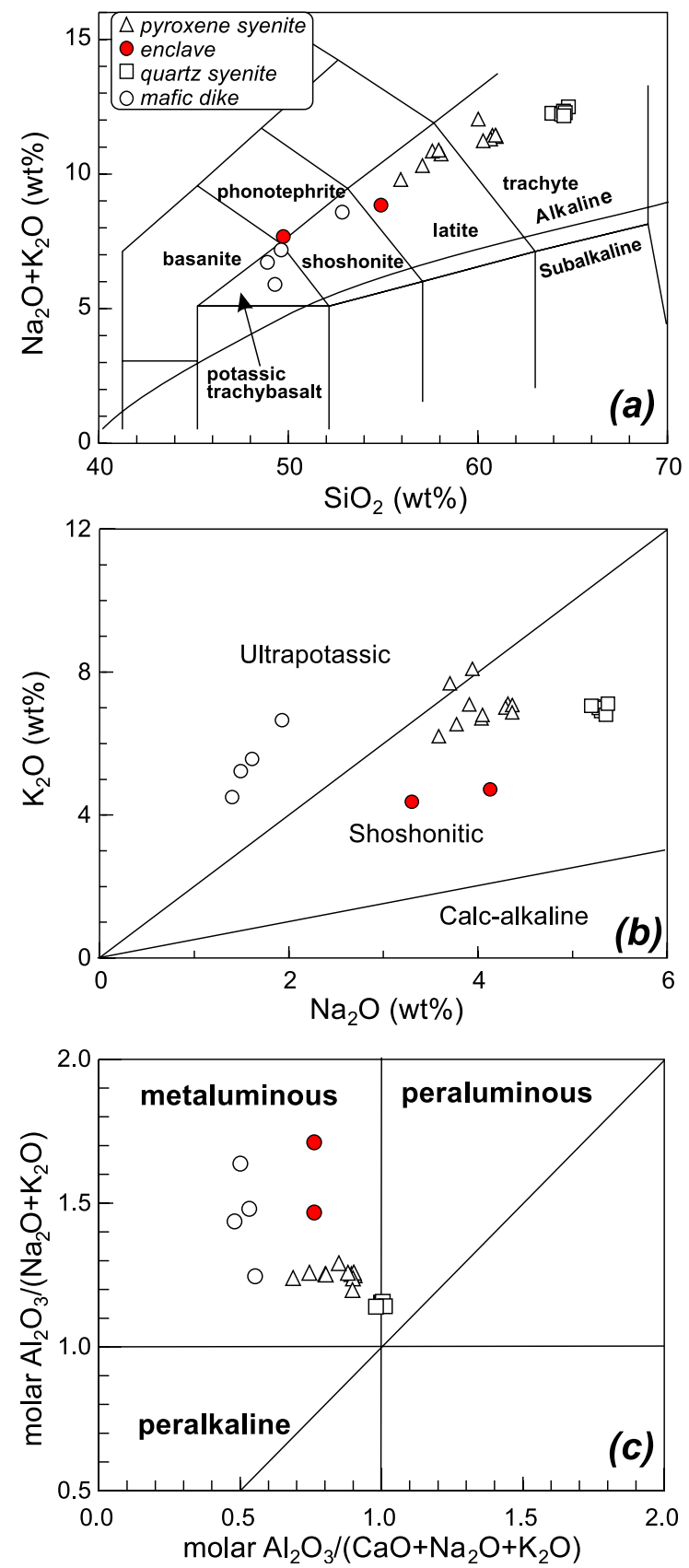

Fig. 4. Classification of the Jiazishan Complex on the basis of (a) the TAS diagram. All the major element data have been recalculated to $100 \%$ on a $\mathrm{H}_{2} \mathrm{O}$ - and $\mathrm{CO}_{2}$-free basis (after Middlemost, 1994; Le Maitre, 2002); (b) $\mathrm{K}_{2} \mathrm{O}$ vs. $\mathrm{Na}_{2} \mathrm{O}$ diagram, showing the Jiazishan Complex to be shoshonitic and ultrapotassic (after Middlemost, 1972); (c) A/NK vs. A/CNK plot. All samples except for quartz syenites fall in the metaluminous field. with steep slopes $\left(\mathrm{La}_{N} / \mathrm{Yb}_{N}=28-37\right)$ and small or no negative $\mathrm{Eu}$ anomalies. The quartz syenites (Fig. $8 \mathrm{~b})$ are also enriched in LREE, with $\mathrm{La}_{N} / \mathrm{Yb}_{N}$ values of 19-28. The distinctive negative $\mathrm{Eu}$ anomalies (Fig. 8b) and low Ti, Ba and Sr contents suggest that quartz syenites are highly differentiated rocks, in contrast to the pyroxene syenites. The chondrite-normalized REE patterns of the mafic dikes (Fig. 8c) are also steeply inclined and show relative enrichment of LREE over HREE $\left(\mathrm{La}_{N} /\right.$ $\left.\mathrm{Yb}_{N}=29-43\right)$ without Eu anomalies. They have lower total REE contents than either the pyroxene or quartz syenites.

In the primitive mantle-normalized trace element diagrams, pyroxene syenites (Fig. 9a) have highly variable trace element contents, particularly for $\mathrm{Ba}$, $\mathrm{Th}, \mathrm{U}, \mathrm{Nb}, \mathrm{Ta}, \mathrm{Zr}$ and REE. They are characterized by enrichment in LILEs (i.e., $\mathrm{Rb}, \mathrm{Ba}, \mathrm{Sr}$, Th and $\mathrm{U}$ ) relative to LREEs (i.e., $\mathrm{La}, \mathrm{Ce}, \mathrm{Pr}, \mathrm{Nd}$ and $\mathrm{Sm}$ ) and HFSEs (i.e., $\mathrm{Nb}, \mathrm{Ta}, \mathrm{P}$ and $\mathrm{Ti}$ ) with $\mathrm{Ba} / \mathrm{La}$ and $\mathrm{La} / \mathrm{Nb}$ ratios of 14-79 and 2.3-13. Quartz syenites have different patterns from the pyroxene syenites (Fig. $9 \mathrm{~b}$ ), with negative $\mathrm{Ba}$ and $\mathrm{Sr}$ anomalies and strong depletion in $\mathrm{P}$ and Ti. Mafic dikes have similar trace element patterns to the pyroxene syenites, but with weak Ti and $\mathrm{P}$ anomalies (Fig. 9c).

\subsection{Nd and Sr isotopes}

Table 4 gives the results of 17 new $\mathrm{Nd}$ and $\mathrm{Sr}$ isotopic analyses which cover the major rock types of the Jiazishan Complex. The data are shown in a plot (Fig. 10) of $\varepsilon_{\mathrm{Nd}}(t)$ vs. initial ${ }^{87} \mathrm{Sr} /{ }^{86} \mathrm{Sr}$ ratios and are compared on that diagram with published compositional fields for Late Mesozoic volcanic rocks from the Jiaodong Peninsula (Fan et al., 2001; Guo et al., 2001a), granites and lamprophyres (Yang, 2000; Yang et al., 2004). Also shown are compositional trends from available data for components of the lower and upper crust in the Jiaodong Peninsula (Jahn et al., 1999). Data for the Early Cretaceous samples were recalculated to a common age of $125 \mathrm{Ma}$.

The pyroxene syenites and quartz syenites from the Jiazishan Complex have very similar $\mathrm{Nd}$ and $\mathrm{Sr}$ isotopic ratios despite their geochemical differences. They have strongly negative $\varepsilon_{\mathrm{Nd}}(t)$ values of -15.2 to- 16.2 and low radiogenic initial ${ }^{87} \mathrm{Sr} /{ }^{86} \mathrm{Sr}$ ratios of 

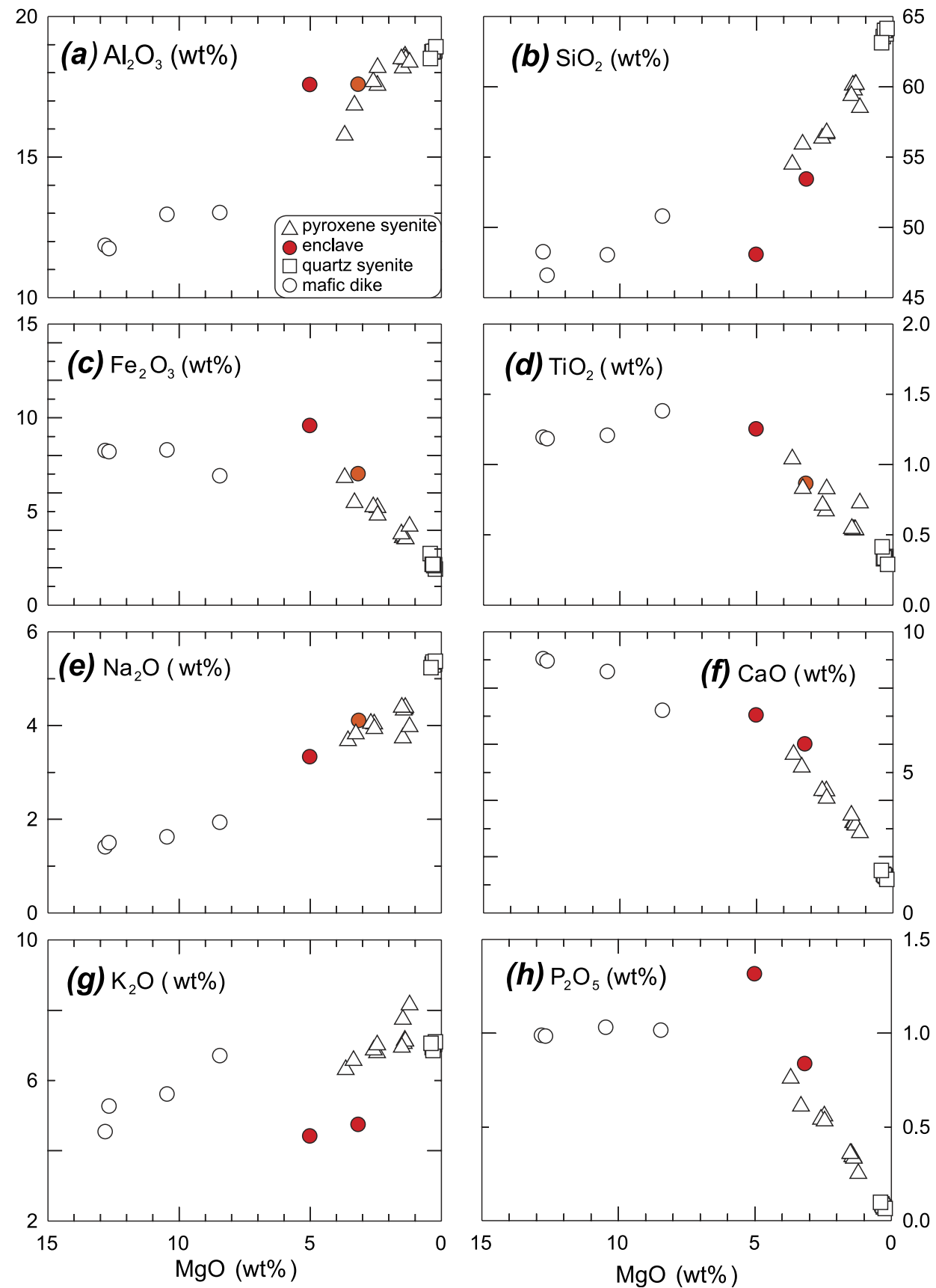

Fig. 5. Major element oxides vs. $\mathrm{MgO}$ plots for the Jiazishan Complex. (a) $\mathrm{Al}_{2} \mathrm{O}_{3}$; (b) $\mathrm{SiO}_{2}$; (c) $\mathrm{Fe}_{2} \mathrm{O}_{3}$; (d) $\mathrm{TiO}_{2}$; (e) $\mathrm{Na}_{2} \mathrm{O}$; (f) $\mathrm{CaO}$; (g) $\mathrm{K}_{2} \mathrm{O}$ and (h) $\mathrm{P}_{2} \mathrm{O}_{5}$.

0.70659-0.70708. The mafic dikes have similar $\varepsilon_{\mathrm{Nd}}(t)$ values $(\sim-16.5)$ to the syenites but have more radiogenic initial ${ }^{87} \mathrm{Sr} /{ }^{86} \mathrm{Sr}$ ratios $(0.70722-0.70728)$ than the syenites. The mafic enclaves have slightly higher $\varepsilon_{\mathrm{Nd}}(t)$ values $(-14.6$ to -14.8$)$ and less radiogenic initial ${ }^{87} \mathrm{Sr} /{ }^{86} \mathrm{Sr}$ ratios $(0.70644-0.70658)$ 

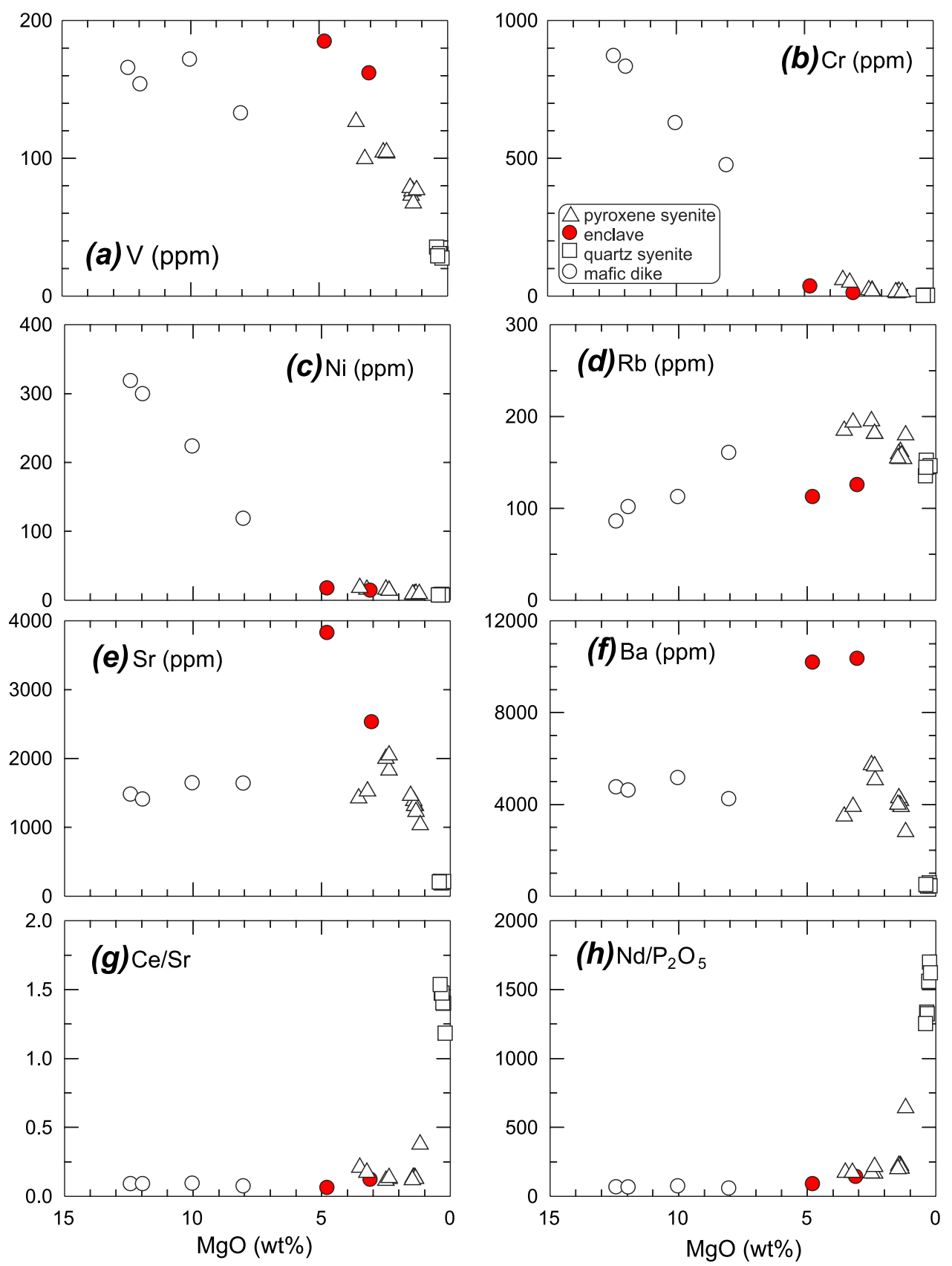

Fig. 6. Selected trace element and elemental ratios vs $\mathrm{MgO}$ plots for the Jiazishan Complex. (a) V; (b) $\mathrm{Cr}$; (c) $\mathrm{Ni}$; (d) Rb; (e) $\mathrm{Sr}$; (f) $\mathrm{Ba}$; (g) Ce/Pb and (h) $\mathrm{Nd} / \mathrm{P}_{2} \mathrm{O}_{5}$.

than either the syenites or the mafic dikes (Fig. 10). All these rocks plot near the field of Early Cretaceous mafic volcanic rocks but far from those of
Late Jurassic to Early Cretaceous granites and mafic dikes, lower crust and upper crust (Fig. 10). The model age $\left(T_{\mathrm{DM}}\right.$, depleted mantle age, $\left.\mathrm{Sm}-\mathrm{Nd}\right)$ of 

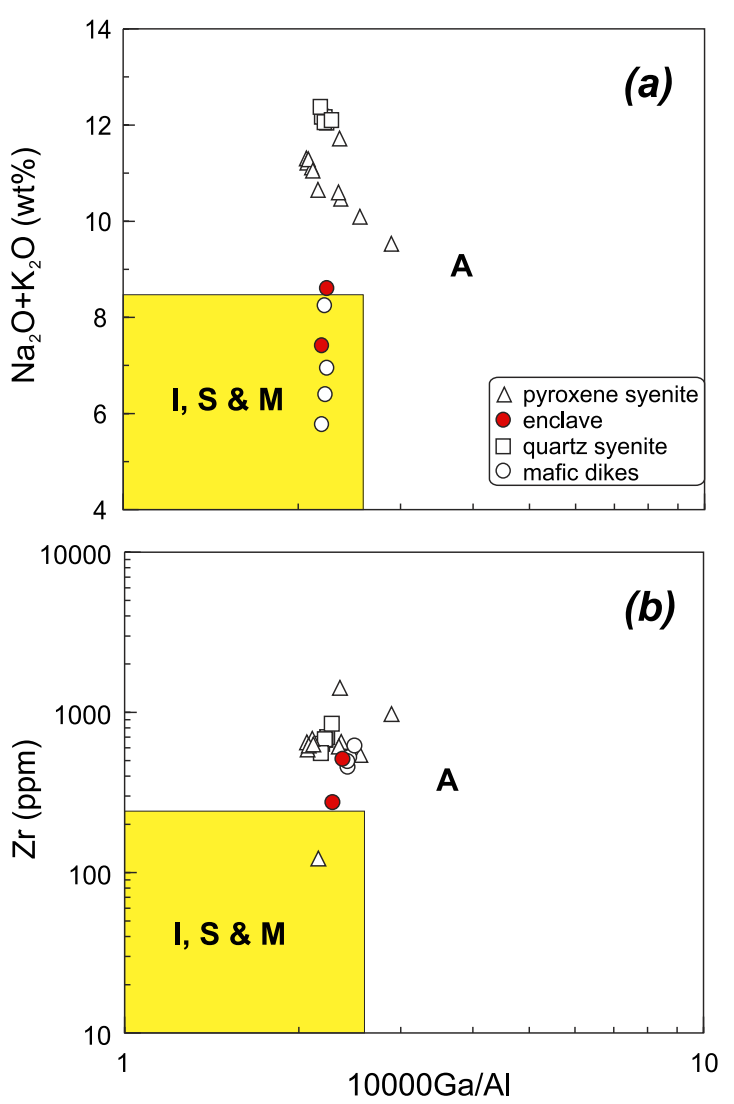

Fig. 7. (a) $\mathrm{Na}_{2} \mathrm{O}+\mathrm{K}_{2} \mathrm{O}$ and (b) $\mathrm{Zr}$ vs. $10000 \mathrm{Ga} / \mathrm{Al}$ discrimination diagrams showing that the syenites are A-type granites. After Whalen et al. (1987), I=I-type, S=S-type and M=M-type granitoids.

the Jiazishan samples is mainly in the range of 2.0$1.7 \mathrm{Ga}$ (Table 4).

\section{Petrogenesis of the mafic dikes}

\subsection{Mantle source}

The low silica contents (46.6-50.8 wt.\%) and relatively high concentrations of $\mathrm{MgO}(8.1-12.4$ wt.\%), Cr (477-872 ppm) and $\mathrm{Ni}(119-318 \mathrm{ppm})$ suggest that the mafic dikes were derived from an ultramafic source. Crustal rocks can be ruled out as possible sources because experimental evidence shows that partial melting of any of the older, exposed crustal rocks (e.g., Hirajima et al., 1990; Yang et al., 1993; Zhang et al., 1994, 1995; Kato et al., 1997) and lower crustal intermediate granulites (Gao et al., 1998a,b) in the deep crust would produce high-Si, low-Mg liquids (i.e., granitoid liquids; Rapp et al., 2003), not the highly magnesian magmas present in the Jiazishan Complex.

The parental magmas to the Jiazishan ultrapotassic mafic dikes have undergone variable amounts of clinopyroxene and olivine fractionation inferred from the correlation between $\mathrm{Cr}, \mathrm{Ni}$ and $\mathrm{MgO}$ (Fig. 6b and c). Plagioclase was not an important fractionated phase, given the absence of negative Eu anomalies (Fig. 8c) and the occurrence of plagioclase phenocrysts in these lavas. Clinopyroxene and olivine were the main fractionated phases (see below). However, mafic lavas (such as JZS-D-3

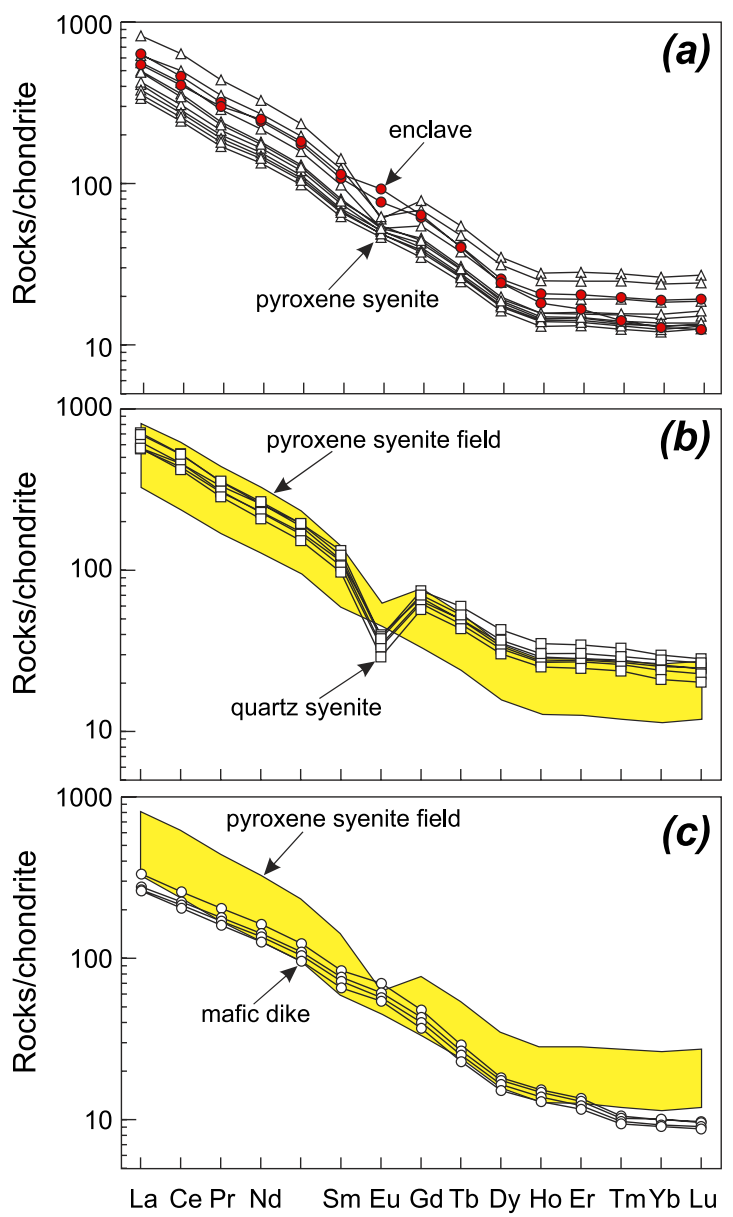

Fig. 8. Chondrite-normalized REE patterns for (a) pyroxene syenite, (b) quartz syenite and (c) mafic dike from Jiazishan Complex. Note that all the quartz syenites have negative $\mathrm{Eu}$ anomalies. The chondrite values are from Sun and McDonough (1989). 


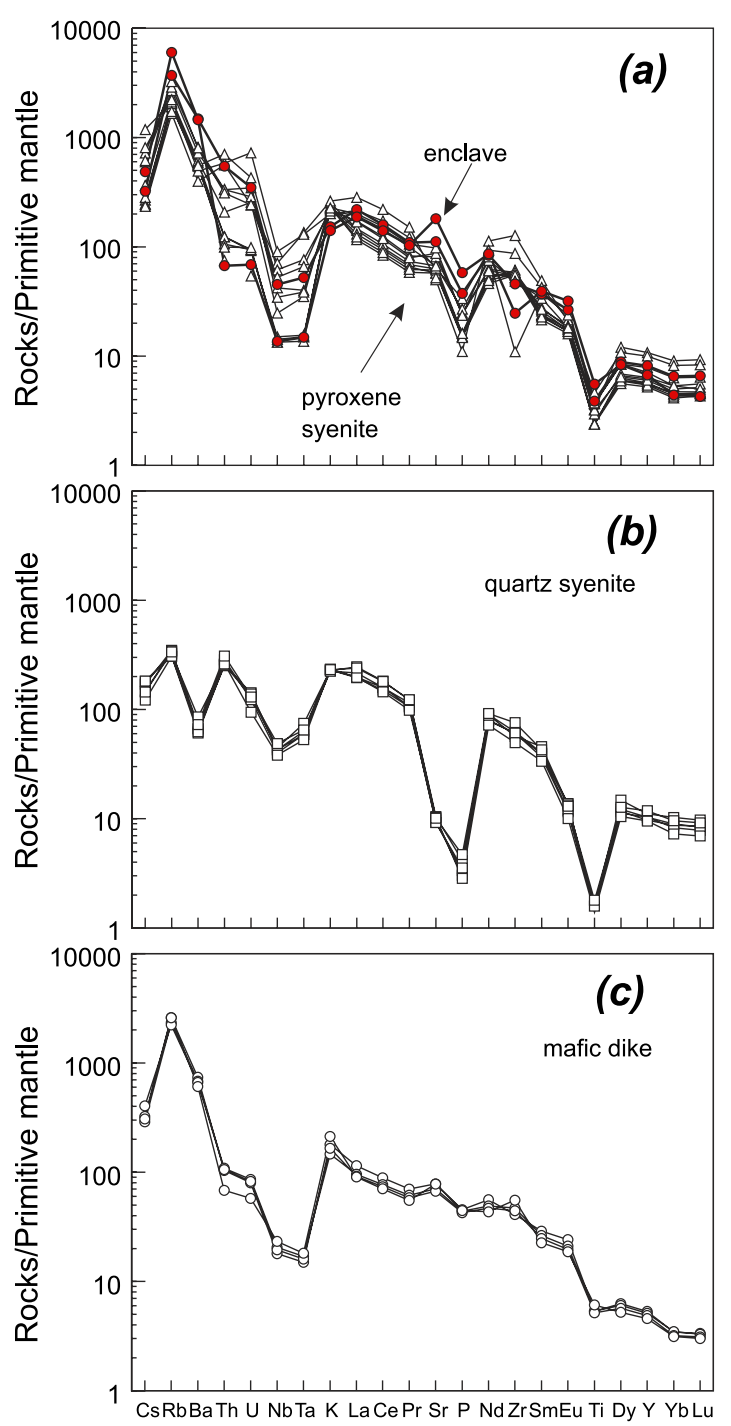

Fig. 9. Primitive mantle (PM) normalized diagrams for (a) pyroxene syenite and enclave, (b) quartz syenite and (c) mafic dike. Elements are arranged in the order of decreasing incompatibility from left to right. The PM values are from Sun and McDonough (1989).

and 4) with high $\mathrm{MgO}$ contents and $\mathrm{Mg} \# \approx 73$ are near-primary melts.

The parental magmas, represented by samples JZS-D-3 and 4, have 46.6-48.3 wt. $\% \mathrm{SiO}_{2}$ and 12.0-12.4 wt.\% $\mathrm{MgO}$, as well as elevated $\mathrm{Mg} \#$ ( 73.5), Cr (834-873 ppm) and Ni (300-319 ppm), moderately low $\mathrm{CaO} / \mathrm{Al}_{2} \mathrm{O}_{3}(\sim 0.76)$ and low $\mathrm{TiO}_{2}$ ( $\sim 1.12$ wt.\%). The composition of these mafic dikes is similar to that of experimental melts from depleted peridotite (Falloon et al., 1988), indicating a dominantly refractory lithospheric mantle contribution to the magma. The mafic dikes also share high $\mathrm{La} / \mathrm{Sm}$ ( $\sim$ ) and depleted heavy REE and HFSE signatures, along with low $\mathrm{Ti} / \mathrm{V}$ and $\mathrm{Ti} / \mathrm{Zr}$ ratios and enrichment in $\mathrm{Zr}$ relative to $\mathrm{Sm}$ (Table 3 and Fig. 9c). The trace element systematics of the mafic dikes signify derivation from a refractory peridotite more depleted than the residua from MORB generation (Hickey and Frey, 1982), which has been overprinted by an enriched component.

The high $\mathrm{K}_{2} \mathrm{O}$ content ( $>4$ wt. $\%$ ) of the mafic dikes requires a potassic phase in the source region. Melts in equilibrium with phlogopite are expected to have significantly higher $\mathrm{Rb} / \mathrm{Sr}$ and lower $\mathrm{Ba} / \mathrm{Rb}$ values than those formed from amphibole-bearing sources (Furman and Graham, 1999). High Ba/Rb (>45) and relatively low $\mathrm{Rb} / \mathrm{Sr}(<0.1)$ ratios strongly suggest that the parental magmas to the mafic dikes formed through partial melting of an amphibole-bearing source. Therefore, the mafic dikes were derived from partial melting of an amphibole-bearing, refractory lithospheric mantle source.

\subsection{Lithospheric mantle beneath the Sulu region}

The incompatible element contents and negative $\varepsilon_{\mathrm{Nd}}(t)$ values $(\sim-16.5)$ of these mafic dikes are more typical of crust-derived melts. The possibility remains that these chemical signatures resulted from crustal contamination during transport through the continental crust. However, the low silica and high $\mathrm{MgO}$ and the lack of correlation of isotopic compositions with $\mathrm{MgO}$ (Fig. 11) preclude significant crustal assimilation during magma ascent.

$\mathrm{The} \mathrm{Nb} / \mathrm{U}(7.6-13.7)$ and $\mathrm{Ce} / \mathrm{Pb}(7.6-9.9)$ ratios for the Jiazishan mafic dike are significantly lower than in mid-ocean ridge basalt or ocean island basalt (47 and 27, Hofmann et al., 1986), indicating the involvement of crustal components in their source region. The depletion of HFSEs relative to LILEs and LREEs (Fig. 9c) is usually considered to be indicative of arc magmas or magmas derived from ancient crust. However, $\mathrm{O}$ and $\mathrm{H}$ isotopic evidence indicates that the process of continental subduction is characterized by the relative lack of fluids (Zheng et al., 2003). Therefore, no significant amount of slabreleased fluids or melts metasomatized the overlying 


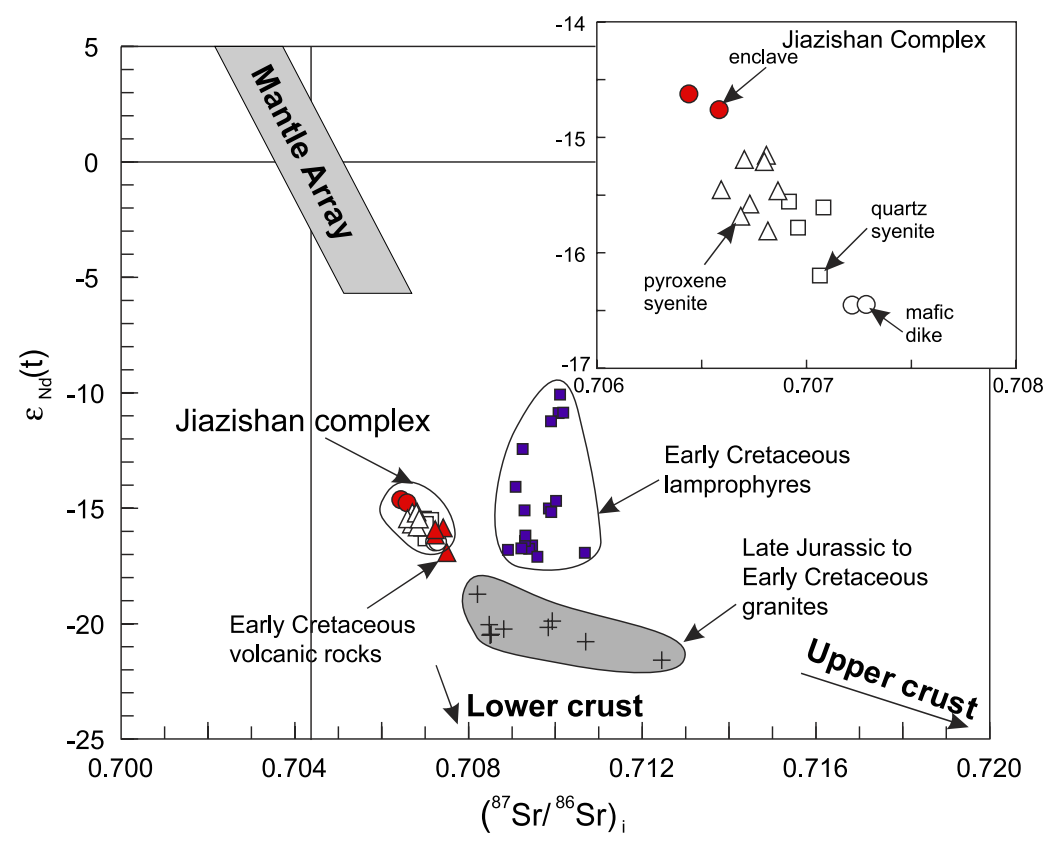

Fig. 10. Sr and $\mathrm{Nd}$ isotopic data from the Jiazishan Complex compared with those of various Late Mesozoic igneous rocks from the Jiaodong Peninsula (Yang, 2000; Fan et al., 2001; Guo et al., 2001a; Yang et al., 2004). Also plotted are trends to Lower and Upper Crust (after Jahn et al., 1999). Inset is enlargement of Jiazishan Complex data set. Initial Sr and Nd isotopic ratios were calculated at $215 \mathrm{Ma}$, whereas those of Late Mesozoic rocks were calculated at $125 \mathrm{Ma}$.

lithospheric mantle during the Triassic subduction. Instead, the Yangtze lithospheric mantle can be considered the candidate that is consistent with the enrichment in incompatible and mobile elements, such as $\mathrm{K}, \mathrm{Rb}, \mathrm{Pb}$ and the LREEs, and depletion in the HFSEs. Nevertheless, the enrichment of mobile elements like $\mathrm{K}$ and $\mathrm{Rb}$ may be caused by the introduction of metamorphic fluids that were derived from decompression exsolution from amphibole, phengite and clinopyroxene and thus their arrival triggered partial melting (Zheng et al., 2003). The slight enrichment of the mafic dike samples in $\mathrm{Rb} / \mathrm{Sr}$ and $\mathrm{Nd} / \mathrm{Sm}$, combined with their high initial ${ }^{87} \mathrm{Sr} /{ }^{86} \mathrm{Sr}$ ratios and negative $\varepsilon_{\mathrm{Nd}}(t)$ values, is consistent with derivation from such an enriched part of the lithosphere.

In summary, the ultrapotassic mafic dike originated from mafic magma that was derived from partial melting of an enriched lithospheric mantle source that was metasomatized by a subducted crustal component prior to magma generation and experienced fractionation of clinopyroxene and olivine. Unlike the subduction of oceanic crust that accompanied a significant release of aqueous fluid to result in arc magmatism, a continental subduction did not produce a sufficient amount of aqueous fluid to metasomatize the overlying lithospheric mantle (Zheng et al., 2003). Therefore, we prefer the subducted Yangtze lithospheric mantle as the source of mafic dike.

\section{Petrogenesis of the syenites}

Assimilation, crystal fractionation (AFC) or magma mixing are usually postulated to explain the occurrence of comagmatic mafic and felsic rocks (e.g., DePaolo, 1981; Devey and Cox, 1987; Marsh, 1989; Mingram et al., 2000). Crustal assimilation, coupled with fractional crystallization, would result in progressive decreases in $\mathrm{Cr}, \mathrm{Ni}, \mathrm{Co}$ and $\mathrm{MgO}$ (or

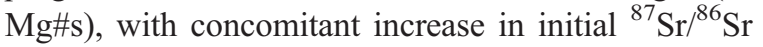
ratios and decrease in $\varepsilon_{\mathrm{Nd}}(t)$ values. Magma mixing should generate mixing curves in the isotopic correlation diagrams and in plots between isotopic ratios and certain elements (e.g., $\mathrm{MgO}$ or $\mathrm{SiO}_{2}$ ). These 


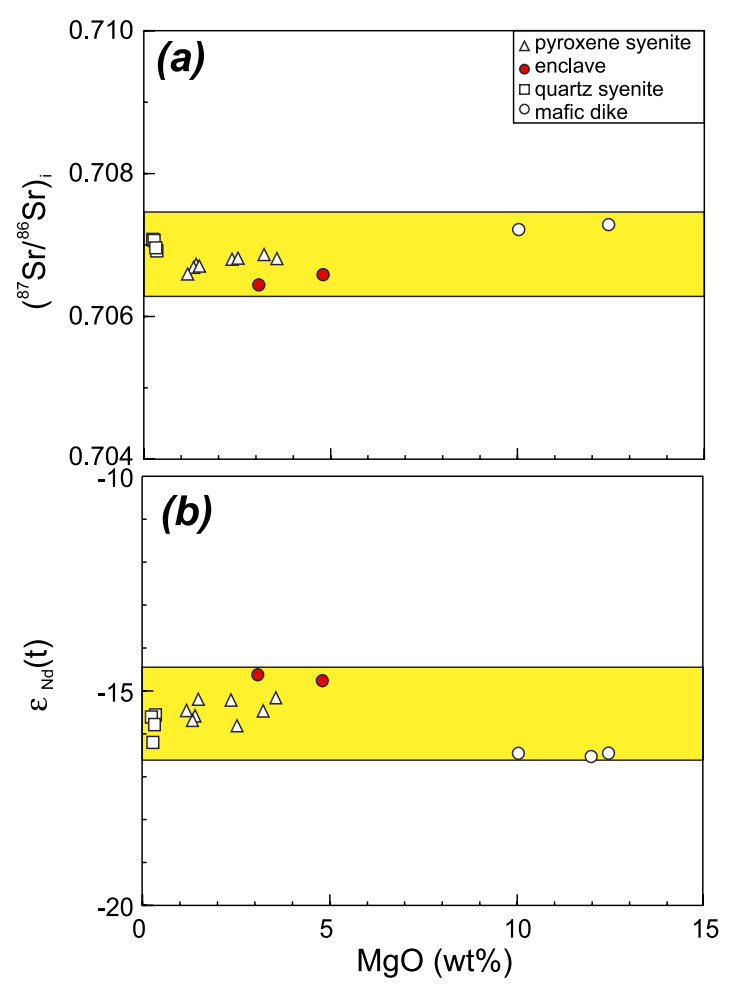

Fig. 11. Plot of (a) initial ${ }^{87} \mathrm{Sr} /{ }^{86} \mathrm{Sr}$ ratio and (b) $\varepsilon_{\mathrm{Nd}}(t)$ value vs. $\mathrm{MgO}$, indicating crystal fractionation. See text for detailed discussion.

features are not observed in the Jiazishan Complex (Figs. 6a-c and 11). The variation in composition within the Jiazishan Complex is not associated with a significant shift in isotopic composition (Fig 11); thus, neither magma mixing nor crustal assimilation are feasible mechanisms.

A major obstacle in identifying petrogenetic lineage among the syenites is that most rocks probably do not represent liquid compositions. The close similarities in $\mathrm{Sr}$ and $\mathrm{Nd}$ isotopic composition between syenites (containing mafic enclaves) and mafic dikes suggest a common source region. The most obvious candidates for the parental magmas of the syenites are similar to those of the mafic dikes, which have low silica (46-48 wt.\%) and relatively high $\mathrm{MgO}$ content ( 12 wt.\%; Mg\# 73.5). Although the dikes have been intruded after the syenites, it is possible that they crystallized from liquids equivalent in composition to those from which the syenites evolved.
On various major and trace element plots (Figs. 5 and 6), the relationship between mafic dike and syenite samples are in agreement with closed-system crystal fractionation of mafic magma. The $\mathrm{CaO}$ content decreases with decreasing $\mathrm{MgO}$ contents (Fig. 5a). The $\mathrm{Fe}_{2} \mathrm{O}_{3}$ vs. $\mathrm{MgO}$ is similar to that of $\mathrm{CaO}$ vs. $\mathrm{MgO}$ in that it steepens with declining $\mathrm{MgO}$ content (Fig. 5c and f). Cr, on the other hand, shows a continual decline as $\mathrm{MgO}$ decreases down to $\mathrm{MgO} 3$ wt.\%, when the $\mathrm{Cr}$ content becomes zero (Fig. 6b). As extensive clinopyroxene and feldspar fractionation would strongly alter the $\mathrm{Ca} / \mathrm{Al}$ ratio of the melt, these two observations are consistent with continuous fractionation of pyroxene and feldspar and the onset of magnetite fractionation from $\mathrm{MgO}<3$ wt.\%. This is supported on the $\mathrm{Ni}$ and $\mathrm{V}$ vs. $\mathrm{Cr}$ diagrams (Fig. 12a and b) in which the variations in the mafic dikes and pyroxene syenites are consistent
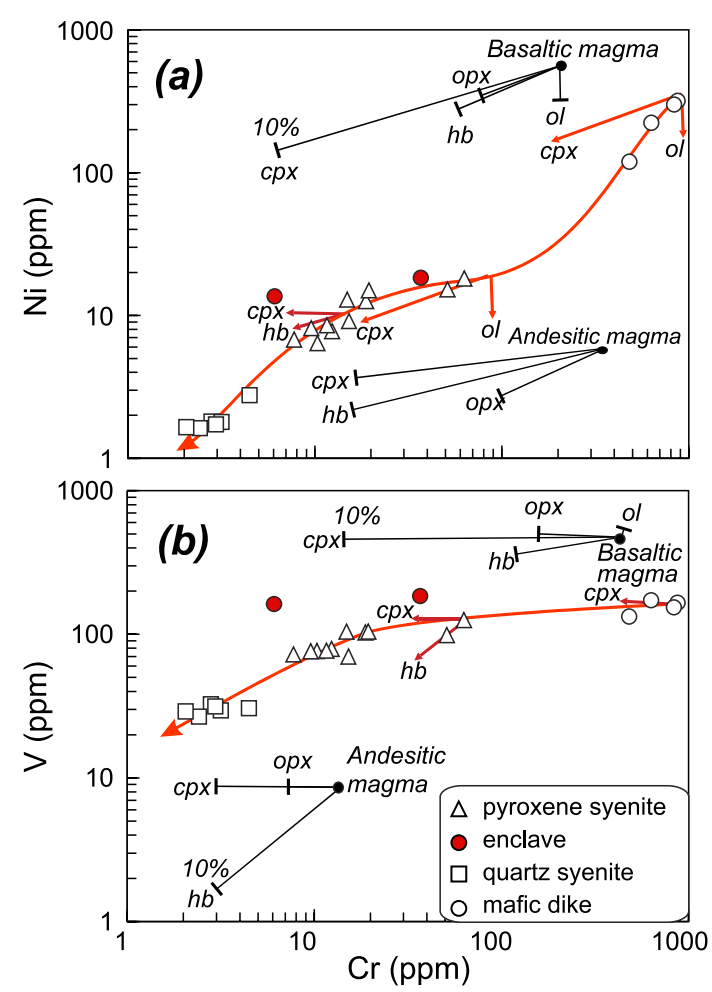

Fig. 12. (a) $\mathrm{Ni}$ and (b) $\mathrm{V}$ vs. Cr diagrams showing olivine- and clinopyroxene-dominated fractionation in the evolution of parental magmas to the Jiazishan Complex. Partition coefficients are from Rollinson (1993). 
with fractionation of clinopyroxene and olivine. The quartz syenites have lower $\mathrm{Cr}, \mathrm{Ni}, \mathrm{Co}$ and $\mathrm{MgO}$, perhaps the result of these magmas having passed the peritectic where clinopyroxene and olivine disappear and feldspar fractionates.

The plots of $\mathrm{Al}_{2} \mathrm{O}_{3}$ and $\mathrm{Sr}$ vs. $\mathrm{MgO}$ are similar (Figs. 5a and 6e). The $\mathrm{Al}_{2} \mathrm{O}_{3}$ content increases as $\mathrm{MgO}$ decreases from 13 to $\sim 2$ wt. $\%$ and shows a sudden decline for $\mathrm{MgO}$ less than $\sim 2 \mathrm{wt} . \%$. Sr shows a general increase as $\mathrm{MgO}$ decreases to about $\mathrm{MgO}=5 \mathrm{wt} . \%$, then shows a steep decline as $\mathrm{MgO}$ decreases further. These plots are consistent with feldspar fractionation below $\mathrm{MgO} \sim 5$ wt.\%, which may explain the lack of $\mathrm{Eu}$ anomalies in the pyroxene syenites and mafic dikes with $\mathrm{MgO}>5$ wt.\% (Fig. 9a and c). Feldspar fractionation is also supported by significant depletions in $\mathrm{Sr}, \mathrm{Ba}$ and $\mathrm{Eu}$ shown in the mantle-normalized trace element patterns (Figs. 8b and 9b). Negative Eu anomalies, combined with decreases in $\mathrm{Ba}$ and $\mathrm{Sr}$ (Fig. 13a and b), indicate that alkali feldspar and plagioclase have been removed during magma evolution. In the $\mathrm{Rb} / \mathrm{Sr}$ and $\mathrm{Ba}$ vs. $\mathrm{Sr}$ diagrams (Fig. 13c and d), decrease in $\mathrm{Ba}$ contents and increase in $\mathrm{Rb} / \mathrm{Sr}$ ratios with decreasing $\mathrm{Sr}$ concentrations are the result of fractionation of alkali feldspar and plagioclase with biotite.

In addition to major phases, accessory minerals would have controlled much of the REE variation. The decrease in REE with increasing $\mathrm{SiO}_{2}$ contents (Table 3) suggests a separation of minerals with high partition coefficients $\left(K_{\mathrm{d}}\right)$, such as apatite, titanite, zircon, allanite and monazite, all of which are important accessory minerals in these rocks. The sharp $\mathrm{P}_{2} \mathrm{O}_{5}$ decrease and $\mathrm{Nd} / \mathrm{P}_{2} \mathrm{O}_{5}$ increase through pyroxene syenites to quartz syenites (Figs. $5 \mathrm{~h}$ and $6 \mathrm{~h}$ ) are consistent with progressive removal of apatite. Accessory allanite (increasing $\mathrm{Ce} / \mathrm{Sr}$, Fig. $6 \mathrm{~g}$ ) is probably involved. Limited $\mathrm{Zr}$ variation restricts the involvement of zircon.

On the basis of the geochemical and isotopic data, we can conclude that the Jiazishan syenites
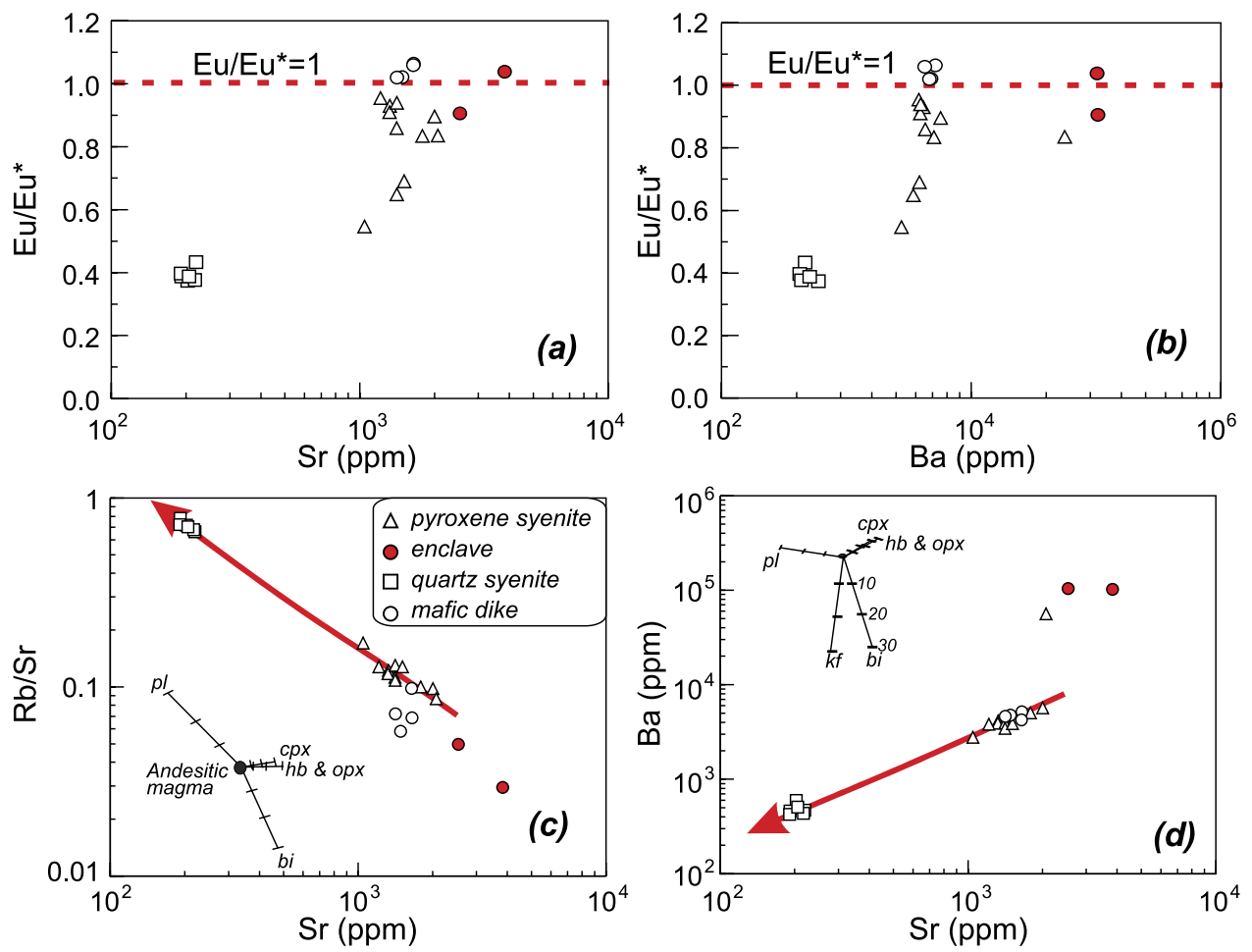

Fig. 13. Eu/Eu* vs. (a) Sr and (b) Ba. (c) Rb/Sr and (d) Ba vs. Sr diagrams showing plagioclase-, K-feldspar- and biotite-dominated fractionation in the evolution of the syenitic magma. Partition coefficients are from Rollinson (1993). 
were derived from an enriched mantle source, similar to that of the mafic dikes. Major and trace element trends can be explained by the switch from clinopyroxene- and olivine-dominated crystallization, controlling evolution of the mafic magmas to metaluminous pyroxene syenite, to biotite- and plagioclase-dominated crystallization, with minor hornblende and accessory mineral contribution, controlling the pyroxene syenite to quartz syenite trend, i.e., A-type granites.

\section{Tectonic implications}

Field relationships, petrological, geochronological and geochemical data emphasize that the syenites and mafic dike from the Jiazishan Complex in the Sulu Orogenic belt were derived by partial melting of a metasomatized, refractory lithospheric mantle source, displaying features similar to other alkaline rocks referred to in the literature as post-collisional (Sylvester, 1989) or post-orogenic/anorogenic syenites (Bonin, 1990). Bonin (1990) proposed that alkaline granitoids post-dating a major orogenic episode can be divided into two groups, i.e., postorogenic (PO) and early anorogenic (EA) granitoids. Post-orogenic magmas are characterized by $\mathrm{Mg} / \mathrm{Mn}$ rich mafic minerals, high $\mathrm{Ba}$ and $\mathrm{Sr}$ abundances and crustal $\mathrm{Sr}$ isotopic signatures, whereas the early anorogenic granitoids are characterized by Fe-rich mafic mineral assemblages, low $\mathrm{Ba}$ and $\mathrm{Sr}$ abundances and low initial $\mathrm{Sr}$ isotopic ratios. The transition from $\mathrm{PO}$ to EA types takes place within a rather short time period (10 Ma long) and has been ascribed to a new mantle source replacing an old complex system of mixed oceanic-continental crustmantle sources and producing alkaline melts (Bonin et al., 1998).

The Jiazishan intrusive suite belongs to the PO group of alkaline rocks. Ages of emplacement (215$200 \mathrm{Ma}$ ) indicate the magmatism post-dates the UHP metamorphic event at 240 to $220 \mathrm{Ma}$ and thus the continental collision between North China and Yangtze cratons. Furthermore, the ultrapotassic basic magmas of the Jiazishan Complex were derived from an enriched lithsopheric mantle source without addition of new mantle material (e.g., asthenospheric mantle). They are also distinguished geochemically and by tectonic setting from the anorogenic Na-rich granitoid suites of alkaline ring complexes derived from OIB-type mantle sources (e.g., Bonin, 1990; Bonin et al., 1998).

Chen et al. (2003) suggested that these syenites were syn-orogenic granitoids, resulting from oceanic slab breakoff of the buoyant continental lithosphere during subduction (Davies and von Blanckenburg, 1995; Chen et al., 2003). However, zircon SHRIMP $\mathrm{U}-\mathrm{Pb}$ data and inferred $P-T$ paths of metamorphic rocks show that the ultrahigh pressure metamorphic event occurred at 240 to $230 \mathrm{Ma}$, with a late amphibolite facies retrogressive overprint at 220 to 200 Ma (Hacker et al., 1998; Webb et al., 1999; Zheng et al., 2002; Liu et al., 2004), indicating the protoliths of UHP metamorphic rocks were subducted to mantle depths in the Early-Middle Triassic and exhumated to mid-crustal levels in the Late Triassic. Furthermore, the syenites and mafic dikes of the Jiazishan Complex have significant arc signatures such as enrichment in LILE and LREE and depletion in HFSE (Fig. 9). Geochemical and $\mathrm{Sr}$ and $\mathrm{Nd}$ isotopic data indicate that they were derived from an enriched lithospheric mantle and formed by closed-system fractionation of their parental magmas. Because small fractions of K-rich melt can be produced by fluid-absent phengite dehydration-melting of metabasalts (flush melting) (Schmidt and Poli, 2003), Zheng et al. (2003) advocated that this mechanism is responsible for the generation of the Late Triassic potassic-ultrapotassic rocks in the Dabie-Sulu orogenic belt and thus classified them as the product of syn-exhumation magmatism rather than syn-collisional magmatism. In this regard, partial melting of the subducted Yangtze lithospheric mantle and its overlying lower crust after the breakoff is principally capable of generating the observed geochemical and isotopic features for both mafic dike and syenites. They are distinguished geochemically and tectonically from those syn-collisional granites which are generally peraluminous granitoids (granodiorites and leucogranite) and K-rich calc-alkaline granitoids (monzogranites) (Barbarin, 1990). In addition, slab breakoff should induce a linear heat pulse along the subduction zone that produces a long linear belt of high-K calc-alkaline bodies associated with highor low-grade regional metamorphism (Davies and 
von Blanckenburg, 1995; Atherton and Ghani, 2002). These have not been found in the DabieSulu UHP belt. In contrast, there is a large Triassic granitoid belt in southern Qinling (Sun et al., 2002), but no UHP metamorphic rocks were ever reported there.

An alternative possibility is lithospheric thinning and crustal extension induced by convective instability of a thickened mantle boundary layer (Houseman et al., 1981). The change in potential energy in the remaining lithosphere would then lead to a sudden uplift of the Sulu orogen (e.g., England and Houseman, 1989; Houseman and England, 1993). This is evidenced by the $\mathrm{Sm}-\mathrm{Nd}$ and $\mathrm{Rb}-\mathrm{Sr}$ isotopic chronology of UHP metamorphic rocks and their country rocks, which distinguish two stages of rapid cooling of the deep-subducted slab corresponding to two stages of fast uplift (Li et al., 2003): initial rapid uplifting and cooling subsequent to the peak UHP metamorphic event may be caused by slab breakoff, and later rapid cooling may be caused by partial delamination due to the convective removal of lithsopheric mantle and related extension. Davies and von Blanckenburg (1995) suggested that slab breakoff in the Dabie-Sulu orogenic belt occurred at great depth to allow the subduction of crustal rocks to presuures of $4 \mathrm{GPa}(>130 \mathrm{~km})$. Linear magmatism would occur with breakoff at such great depths, which is not observed in the Dabie-Sulu orogenic belt. Consequently, the Jiazishan syenites and ultrapotassic dike would result from the convective removal of the lower continental lithospheric mantle, which triggers crustal extension and decompressional melting of subducted lithospheric mantle. These rocks were emplaced where there is transition from continental plate convergence to continental plate divergence and may be good indicators of major change in the geodynamic environment.

\section{Concluding remarks}

The zircon $\mathrm{U}-\mathrm{Pb}$ and ${ }^{40} \mathrm{Ar} /{ }^{39} \mathrm{Ar}$ ages of the Jiazishan syenites and mafic dikes in the Sulu UHP belt indicate that they evolved between 215 and $201 \mathrm{Ma}$, post-dating the UHP metamorphism due to continental collision of the North China and
Yangtze cratons. The suite has the characteristics of post-orogenic alkaline sequences as defined by Bonin, (1990, 1998), i.e., alkaline pyroxene syenite-quartz syenite-ultrapotassic mafic dike association, representing the last magmatic event of the Sulu orogenesis due to partial melting of the subducted Yangtze lithospheric mantle during exhumation. The Jiazishan syenites and mafic dike belong to the potassic to ultrapotassic series and are of alkaline affinity. Field relations, petrography, geochemistry and isotopic composition define an evolution of lithospheric mantle-derived magmas that have experienced extensive fractionation and minor contamination by crustal material. The silica-saturated Atype magmatism was not an intracrustal differentiation process but involved redistribution of mass vertically within the lithosphere. Partial melting occurred in a post-orogenic setting related to lithospheric removal and crustal extension induced by convective instability of a thickened mantle boundary layer and was not directly related to subduction. Interpretation of the data leads to an integrated model of syenite genesis in a post-orogenic extensional setting.

\section{Acknowledgements}

The authors would like to thank G. Nelson Eby, Roberta Rudnick and an anonymous reviewer for their constructive reviews of this manuscript. Prof. Yong-Fei Zheng is acknowledged for his suggestions and revisions on the revised version of the manuscript. J.H. Yang benefited from a 1-year stay in the Department of Geosciences, National Taiwan University. We thank Chao-Feng Li for helping analyze $\mathrm{Sr}$ and $\mathrm{Nd}$ isotopes and Jing-Zhang Shi for help with ${ }^{40} \mathrm{Ar} /{ }^{39} \mathrm{Ar}$ dating. The SHRIMP Laboratory at Curtin University is supported by the Australian Research Council and is operated by a consortium composed of Curtin University of Technology, the University of Western Australia and the Geological Survey of Western Australia. This study was supported by the National Science Foundation of China (Grant nos. 40133020, 40203005, 40325006 and 40132020) and the Chinese Academy of Sciences (Grant no. KZCX1-07 and "Funds for Hundred Outstanding Talents Plan". [RR] 


\section{Appendix A}

Table A

Measured and recommended trace element data (ppm) for rock standards

\begin{tabular}{|c|c|c|c|c|c|c|c|c|c|c|c|c|c|c|c|c|c|}
\hline & AGV-1 & AGV-1 & AGV-1 & $\mathrm{AGV}-1^{\mathrm{a}}$ & BCR-2 & BCR-2 ${ }^{\mathrm{a}}$ & BHVO-2 & BHVO-2 & $\mathrm{BHVO}^{\mathrm{a}}$ & BIR-1 & BIR-1 & BIR-1 ${ }^{\mathrm{a}}$ & JB-1 & JB-1 & $\mathrm{JB}-1^{\mathrm{a}}$ & JG-1 & $\mathrm{JG}-1^{\mathrm{a}}$ \\
\hline V & 109 & 118 & 115 & $120 \pm 11$ & 408 & $416 \pm 14$ & 283 & 320 & $317 \pm 3$ & 315 & 316 & $310 \pm 11$ & 195 & 195 & $211 \pm 20$ & 26 & $25.2 \pm 3.7$ \\
\hline RSD \% & 3.7 & 6.3 & 0.9 & & 0.9 & & 1.9 & 1.3 & & 3.9 & 1.8 & & 0.2 & 0.2 & & 1.2 & \\
\hline $\mathrm{Cr}$ & 8.16 & 7.59 & 8.33 & $10 \pm 3$ & 17.22 & $18 \pm 2$ & 267 & 278 & $280 \pm 7$ & 375 & 375 & $370 \pm 8$ & 492 & 425 & $425 \pm 63$ & 54.2 & $53 \pm 6.9$ \\
\hline RSD $\%$ & 3.4 & 5.2 & 0.7 & & 4.4 & & 1.6 & 0.8 & & 3.9 & 0.8 & & 1.5 & 0.3 & & 1.2 & \\
\hline Co & 13.9 & 14.4 & 15.9 & $15 \pm 1.2$ & 37.11 & $37 \pm 3$ & 41.8 & 46.6 & $45 \pm 7$ & 50.6 & 50.7 & $52 \pm 2$ & 43.2 & 37.4 & $38.2 \pm 5.2$ & 4.16 & $4.1 \pm 0.8$ \\
\hline RSD\% & 1.2 & 4.7 & 0.4 & & 2.5 & & 2.8 & 2.5 & & 1.4 & 1.1 & & 0.8 & 0.2 & & 1.4 & \\
\hline $\mathrm{Ni}$ & 14.0 & 14.6 & 16.2 & 16 & 12.71 & & 113 & 123 & $119 \pm 6$ & 164 & 164 & $170 \pm 6$ & 155 & 132 & $133 \pm 17$ & 7.6 & $7 \pm 2.6$ \\
\hline RSD \% & 2.7 & 4.3 & 0.3 & & 3.0 & & 3.4 & 2.3 & & 2.44 & 0.97 & & 0.5 & 0.5 & & 1.4 & \\
\hline $\mathrm{Cu}$ & 56.9 & 60.0 & 62.5 & $60 \pm 6$ & 21.59 & $19 \pm 2$ & 129 & 130 & $127 \pm 6$ & 123 & 121 & $125 \pm 4$ & 59.8 & 51.3 & $55 \pm 5.5$ & 2.64 & $2.5 \pm 1.2$ \\
\hline RSD \% & 3.1 & 3.9 & 0.5 & & 2.6 & & 3.4 & 0.5 & & 1.2 & 0.7 & & 0.4 & 0.4 & & 1.4 & \\
\hline $\mathrm{Zn}$ & 82.2 & 85.3 & 84.6 & $88 \pm 9$ & 131.38 & $127 \pm 9$ & 104 & 110 & $103 \pm 6$ & 68.0 & 67.3 & $70 \pm 9$ & 92.9 & 82.9 & $85.2 \pm 9.9$ & 45.4 & $41.1 \pm 5.6$ \\
\hline RSD $\%$ & 2.3 & 4.8 & 0.7 & & 1.0 & & 3.1 & 1.7 & & 2.2 & 1.4 & & 2 & 1.0 & & 0.8 & \\
\hline $\mathrm{Ga}$ & 19.7 & 20.5 & 21.2 & $20 \pm 3$ & 23.3 & $23 \pm 2$ & 20.8 & 21.6 & $21.7 \pm 4.0$ & 14.6 & 14.6 & 16 & 18.1 & 17.3 & $17.9 \pm 2.9$ & 17.4 & $17.8 \pm 3.1$ \\
\hline RSD\% & 0.2 & 5.0 & 1.1 & & 0.6 & & 1.8 & 0.1 & & 2.2 & 0.4 & & 0.7 & 0.8 & & 0.8 & \\
\hline $\mathrm{Rb}$ & 68.1 & 69.6 & 67.7 & $67 \pm 1$ & 50.18 & $48 \pm 2$ & 9.73 & 9.63 & $9.8 \pm 1.0$ & 0.21 & 0.14 & $1.0 \pm 0.9$ & 41.4 & 41.0 & $41.3 \pm 5.1$ & 182 & $182 \pm 9.1$ \\
\hline RSD\% & 1.4 & 4.3 & 0.9 & & 0.6 & & 1.9 & 1.9 & & 36.1 & 18.5 & & 1.4 & 0.4 & & 0.7 & \\
\hline $\mathrm{Sr}$ & 644 & 656 & 642 & $660 \pm 9$ & 350.88 & $346 \pm 12$ & 413 & 397 & $389 \pm 6$ & 108 & 108 & $110 \pm 2$ & 444 & 454 & $444 \pm 29$ & 186.0 & $184 \pm 17$ \\
\hline $\mathrm{RSD} \%$ & 1.5 & 6 & 1.3 & & 2.7 & & 2.2 & 0. & & 3. & 2. & & 1. & 0.4 & & 0.6 & \\
\hline Y & 19.4 & 20.0 & 20.0 & $20 \pm 3$ & 38.47 & $37 \pm 2$ & & & $26 \pm 2$ & & 15.6 & $16 \pm 1$ & 24.3 & 24.0 & $24.3 \pm 3.6$ & 31.4 & $30.6 \pm 2.5$ \\
\hline RSD \% & 1.4 & 5.5 & 0.6 & & 0.5 & & 1.2 & 1.4 & & 4.9 & 1.4 & & 1.1 & 0.4 & & 0.6 & \\
\hline $\mathrm{Zr}$ & 220 & 226 & 227 & $227 \pm 18$ & 190.57 & $188 \pm 16$ & 177 & 176 & $172 \pm 6$ & 13.6 & 13.5 & $18 \pm 1$ & 138 & 133 & $141 \pm 22$ & 118 & $111 \pm 27$ \\
\hline RSD $\%$ & 3.8 & 3.9 & 0.7 & & 3.4 & & 0.9 & 1.1 & & 4.9 & 1.2 & & 1.3 & 0.7 & & 0.6 & \\
\hline $\mathrm{Nb}$ & 12.7 & 13.0 & 14.9 & 15 & 11.88 & & 17.8 & 17.4 & $18 \pm 2$ & 0.47 & 0.46 & 0.6 & 35 & 33.6 & $33.3 \pm 6.5$ & 11.4 & $12.4 \pm 1.3$ \\
\hline RSD $\%$ & 1.7 & 4.8 & 0.5 & & 2.3 & & 2. & 1. & & 4.1 & 1.9 & & & 0.8 & & 0.5 & \\
\hline Cs & 1.23 & 1.26 & 1.15 & $1.3 \pm 0.1$ & 1.22 & $1.1 \pm 0.1$ & 0.10 & 0.10 & & & & $0.45 \pm 0.1$ & 1.17 & 1.41 & $1.23 \pm 0.2$ & 9.00 & $10.1 \pm 1.1$ \\
\hline RSD \% & 2.3 & 2.7 & 1.0 & & 2.3 & & 4.3 & 1.3 & & 91 & 13 & & 0.8 & 1.2 & & 0.4 & \\
\hline $\mathrm{Ba}$ & 1172 & 1209 & 1188 & $1230 \pm 16$ & 707.68 & $683 \pm 28$ & 142 & 130 & $130 \pm 13$ & 7.37 & 6.38 & 7 & 477 & 594 & $493 \pm 46$ & 468 & $466 \pm 27$ \\
\hline RSD $\%$ & 0.8 & 2.6 & 0.7 & & 1.7 & & 3.2 & 2.2 & & 17.8 & 2.5 & & 0.5 & 0.5 & & 0.4 & \\
\hline $\mathrm{La}$ & 38.32 & 39.46 & 38.79 & $38 \pm 2$ & 26.72 & $25 \pm 1$ & 15.97 & 15.68 & $15 \pm 1$ & 0.65 & 0.56 & $0.63 \pm 0.1$ & 42.89 & 35.01 & $38.6 \pm 4.3$ & 22.82 & $22.4 \pm 2.7$ \\
\hline RSD $\%$ & 1.0 & 3.5 & 0.7 & & 0.8 & & 2.2 & 1.0 & & 6.9 & 1.5 & & 0.4 & 0.9 & & 0.5 & \\
\hline $\mathrm{Ce}$ & 67.97 & 69.90 & 69.44 & $67 \pm 6$ & 51.57 & $53 \pm 2$ & 39.21 & 40.49 & $38 \pm 2$ & & 1.72 & $1.90 \pm 0.4$ & 74.82 & 61.40 & $67.8 \pm 6.8$ & 45.71 & $45.8 \pm 4.7$ \\
\hline RSD $\%$ & 2.2 & 3.3 & 1.0 & & 1.3 & & 1.9 & 0.6 & & 3.8 & 2.5 & & 0.3 & 0.7 & & 0.8 & \\
\hline $\operatorname{Pr}$ & 7.85 & 8.07 & 8.33 & 7.6 & 6.89 & $6.8 \pm 0.3$ & 5.30 & 5.41 & & 0.35 & 0.34 & $0.5 \pm 0.4$ & 7.44 & 6.29 & $7.01 \pm 0.8$ & 4.87 & $4.83 \pm 1.0$ \\
\hline RSD \% & 1.2 & 4.1 & 0.6 & & 1.7 & & 0.6 & 1.4 & & 2.6 & 1.4 & & 0.3 & 0.4 & & 1.4 & \\
\hline $\mathrm{Nd}$ & 30.88 & 31.31 & 32.04 & $33 \pm 3$ & 30.40 & $28 \pm 2$ & 25.48 & 25.97 & $25.0 \pm 1.8$ & 2.32 & 2.24 & $2.5 \pm 0.7$ & 28.29 & 24.64 & $26.8 \pm 2.3$ & 19.76 & $19.3 \pm 2.5$ \\
\hline
\end{tabular}




\begin{tabular}{|c|c|c|c|c|c|c|c|c|c|c|c|c|c|c|c|c|c|}
\hline & AGV-1 & AGV-1 & AGV-1 & $\mathrm{AGV}-1^{\mathrm{a}}$ & BCR-2 & BCR-2 $^{a}$ & BHVO-2 & BHVO-2 & BHVO- $2^{\mathrm{a}}$ & BIR-1 & BIR-1 & BIR-1 ${ }^{\mathrm{a}}$ & JB-1 & JB-1 & $\mathrm{JB}-1^{\mathrm{a}}$ & JG-1 & $\mathrm{JG}-1^{\mathrm{a}}$ \\
\hline$\overline{\mathrm{RSD}} \%$ & 1.5 & 4.7 & 0.5 & & 1.5 & & 1.7 & 1.7 & & 3.2 & 0.8 & & 0.5 & 1.2 & & 0.7 & \\
\hline $\mathrm{Sm}$ & 5.62 & 5.70 & 5.83 & $5.9 \pm 0.4$ & 6.74 & $6.7 \pm 0.3$ & 6.33 & 6.38 & $6.2 \pm 0.4$ & 1.06 & 1.02 & 1.1 & 5.45 & 4.83 & $5.13 \pm 0.5$ & 4.68 & $4.62 \pm 0.56$ \\
\hline RSD\% & 1.9 & 4.9 & 0.9 & & 0.9 & & 2.4 & 1.1 & & 2.8 & 0.9 & & 1.8 & 1.0 & & 2.1 & \\
\hline $\mathrm{Eu}$ & 1.58 & 1.61 & 1.84 & $1.6 \pm 0.1$ & 1.96 & $2.0 \pm 0.1$ & 2.01 & 2.03 & & 0.46 & 0.44 & $0.55 \pm 0.05$ & 1.50 & 1.31 & $1.49 \pm 0.15$ & 0.78 & $0.73 \pm 0.95$ \\
\hline RSD\% & 1.8 & 3.3 & 0.8 & & 0.9 & & 4.3 & 0.9 & & 0.7 & 2.4 & & 0.8 & 1.1 & & 0.8 & \\
\hline Gd & 4.83 & 4.92 & 5.35 & $5 \pm 0.6$ & 6.60 & $6.8 \pm 0.3$ & 6.11 & 6.04 & $6.3 \pm 0.2$ & 1.53 & 1.48 & $1.8 \pm 0.4$ & 5.14 & 4.48 & $4.90 \pm 0.47$ & 4.23 & $4.28 \pm 0.69$ \\
\hline RSD \% & 2.5 & 3.2 & 1.0 & & 3.2 & & 2.3 & 1.4 & & 1.3 & 2.0 & & 0.7 & 1.3 & & 1.7 & \\
\hline $\mathrm{Tb}$ & 0.66 & 0.68 & 0.73 & $0.7 \pm 0.1$ & 1.11 & $1.07 \pm 0.04$ & 1.00 & 1.02 & 0.9 & 0.35 & 0.33 & $0.41 \pm 0.10$ & 0.84 & 0.76 & $0.82 \pm 0.2$ & 0.81 & $0.78 \pm 0.31$ \\
\hline RSD\% & 3.0 & 5.4 & 0.8 & & 0.9 & & 1.3 & 0.4 & & 1.8 & 1.8 & & 0.7 & 1.5 & & 0.7 & \\
\hline Dy & 3.48 & 3.55 & 3.59 & $3.6 \pm 0.4$ & 6.56 & & 5.57 & 5.37 & & 2.42 & 2.38 & $2.4 \pm 0.3$ & 4.46 & 4.15 & $4.14 \pm 0.38$ & 4.35 & $4.14 \pm 1.22$ \\
\hline RSD\% & 0.6 & 4.9 & 0.8 & & 1.1 & & 2.8 & 2.2 & & 0.9 & 1.4 & & 1.0 & 1.8 & & 0.7 & \\
\hline Ho & 0.65 & 0.67 & 0.70 & & 1.32 & $1.33 \pm 0.06$ & 1.05 & 0.99 & $1.04 \pm 0.04$ & 0.54 & 0.53 & $0.5 \pm 0.1$ & 0.84 & 0.79 & $0.79 \pm 0.098$ & 0.87 & $0.81 \pm 0.23$ \\
\hline RSD \% & 0.7 & 4.0 & 1.1 & & 1.2 & & 1.9 & 2.3 & & 1.5 & 2.1 & & 0.8 & 2.4 & & 0.6 & \\
\hline Er & 1.78 & 1.82 & 1.92 & 1.7 & 3.74 & & 2.73 & 2.54 & & 1.57 & 1.57 & $1.8 \pm 0.3$ & 2.36 & 2.24 & $2.27 \pm 0.19$ & 2.32 & $2.16 \pm 0.65$ \\
\hline RSD \% & 1.9 & 1.6 & 0.9 & & 1.7 & & 2.3 & 2.0 & & 1.93 & 0.86 & & 0.5 & 1.2 & & 0.2 & \\
\hline $\mathrm{Tm}$ & 0.26 & 0.26 & 0.27 & 0.34 & 0.54 & 0.54 & 0.36 & 0.34 & & 0.25 & 0.24 & $0.27 \pm 0.10$ & 0.36 & 0.34 & $0.35 \pm 0.056$ & 0.45 & $0.41 \pm 0.14$ \\
\hline RSD\% & 1.5 & 3.1 & 1.6 & & 2.2 & & 3.5 & 0.7 & & 2.4 & 0.8 & & 2.5 & 1.3 & & 1.9 & \\
\hline $\mathrm{Yb}$ & 1.63 & 1.64 & 1.67 & $1.72 \pm 0.2$ & 3.46 & $3.5 \pm 0.2$ & 2.17 & 2.09 & $2.0 \pm 0.2$ & 1.56 & 1.53 & $1.7 \pm 0.2$ & 2.20 & 2.11 & $2.13 \pm 0.26$ & 2.46 & $2.47 \pm 0.73$ \\
\hline RSD \% & 1.3 & 5.9 & 1.1 & & 2.0 & & 1.9 & 2.7 & & 0.8 & 3.0 & & 1.8 & 0.4 & & 1.3 & \\
\hline $\mathrm{Lu}$ & 0.25 & 0.26 & 0.26 & $0.27 \pm 0.03$ & 0.52 & $0.51 \pm 0.02$ & 0.31 & 0.30 & $0.28 \pm 0.01$ & 0.24 & 0.24 & 0.26 & 0.33 & 0.31 & $0.31 \pm 0.029$ & 0.40 & $0.39 \pm 0.12$ \\
\hline RSD $\%$ & 1.4 & 4.4 & 1.2 & & 4.8 & & 3.4 & 4.5 & & 2.8 & 0.9 & & 0.6 & 1.4 & & 1.0 & \\
\hline $\mathrm{Hf}$ & 4.97 & 4.97 & 5.09 & $5.1 \pm 0.4$ & 4.82 & $4.8 \pm 0.2$ & 4.77 & 4.38 & $4.1 \pm 0.3$ & 0.54 & 0.53 & $0.6 \pm 0.08$ & 3.51 & 3.40 & $3.31 \pm 0.56$ & 3.53 & $3.56 \pm 1.03$ \\
\hline RSD\% & 1.5 & 3.9 & 0.8 & & 1.4 & & 1.1 & 0.6 & & 4.3 & 2.7 & & 0.9 & 0.9 & & 1.1 & \\
\hline $\mathrm{Ta}$ & 0.83 & 0.85 & 1.04 & $0.9 \pm 0.1$ & 0.73 & & 1.29 & 1.18 & 1.4 & 0.04 & 0.04 & $0.06 \pm 0.05$ & 3.25 & 2.88 & $2.93 \pm 0.79$ & 1.79 & $1.79 \pm 0.51$ \\
\hline RSD \% & 1.6 & 4.8 & 5.7 & & 3.0 & & 1.8 & 1.2 & & 7.7 & 1.6 & & 1.1 & 0.8 & & 1.1 & \\
\hline $\mathrm{Pb}$ & 37.0 & 37.3 & 38.1 & $36 \pm 5$ & 11.10 & $11 \pm 2$ & 1.70 & 1.58 & & 3.19 & 3.06 & 3 & 10.1 & 10.1 & $10 \pm 4.1$ & 25.1 & $25.4 \pm 3.1$ \\
\hline RSD \% & 1.0 & 3.3 & 0.5 & & 0.3 & & 1.7 & 2.3 & & 3.6 & 1.5 & & 1.6 & 0.6 & & 1.6 & \\
\hline Th & 6.43 & 6.56 & 6.49 & $6.5 \pm 0.5$ & 6.27 & $6.2 \pm 0.7$ & 1.39 & 1.28 & $1.2 \pm 0.3$ & 0.24 & 0.13 & $0.89 \pm 0.7$ & 8.85 & 9.52 & $9.3 \pm 0.7$ & 13.46 & $13.2 \pm 1.6$ \\
\hline RSD\% & 2.5 & 3.2 & 0.8 & & 1.4 & & 0.9 & 0.8 & & 28.4 & 8.2 & & 0.4 & 0.5 & & 1.0 & \\
\hline $\mathrm{U}$ & 1.85 & 1.91 & 1.93 & $1.92 \pm 0.2$ & 1.56 & $1.69 \pm 0.19$ & 0.46 & 0.43 & & 0.01 & 0.01 & 0.05 & 1.59 & 1.72 & $1.67 \pm 0.28$ & 3.59 & $3.47 \pm 0.71$ \\
\hline RSD \% & 2.0 & 3.7 & 0.5 & & 0.5 & & 3.8 & 1.1 & & 29.9 & 4.3 & & 1.3 & 1.5 & & 0.6 & \\
\hline
\end{tabular}

Recommended data are from:

JB-1 And JG-1: Imai, N., Terashima, S., Itoh, S., Ando, A., 1995. 1994 Compilation of analytical data for minor and trace elements in seventeen GSJ geochemical reference samples. Igneous Rock Series, Geostandards Newsletter 19, 135-213.

BIR-1, BHVO-1 and AGV-1: Govindaraju, K., 1994. 1994 Compilation of Working Values and Descriptions for 383 Geostandards. Geostandards Newsletter 118, 1-158.

BCR-2: Wilson, S.A., 1997. The collection, preparation, and testing of USGS reference material BCR-2, Columbia River, Basalt. U.S. Geological Survey Open-File Report 98-00x. 


\section{References}

Ames, L., Tilton, G.R., Zhou, G.Z., 1993. Timing of collision of the Sino-Korean and Yangtze cratons: U-Pb zircon dating of coesite-bearing eclogites. Geology 21, 339-342.

Atherton, M.P., Ghani, A.A., 2002. Slab breakoff: a model for Caledonian, late granite syn-collisional magmatism in the orthotectonic (metamorphic) zone of Scotland and Donegal, Ireland. Lithos 62, 65-85.

Barbarin, B., 1990. Granitoids: main petrogenetic classifications in relation to origin and tectonic setting. Geol. J. 25, 227-238.

Barker, F., Wones, D.R., Sharp, W.N., Desborough, G.A., 1975. The Pikes Peak batholith, Colorado Front Range, and a model for the origin of the gabbro-anorthosite-syenite-potassic granite suite. Precambrian Res. 2, 97-160.

Bonin, B., 1990. From orogenic to anorogenic settings: evolution of granitoid suites after a major orogenesis. Geol. J. 25, $261-270$.

Bonin, B., Platevoet, B., Vialette, Y., 1987. The geodynamic significance of alkaline magmatism in the Western Mediterranean compared with West Africa. In: Bowden, P., Kinnaird, J. (Eds.), African Geology Reviews, Geol. J., vol. 22, pp. $361-387$.

Bonin, B., Azzouni-Sekkal, A., Bussy, F., Ferrag, S., 1998. Alkali-calcic and alkaline post-orogenic (PO) granite magmatism: petrologic constraints and geodynamic settings. Lithos $45,45-70$.

Brown, P.E., Becker, S.M., 1986. Fractionation, hybridisation and magma-mixing in the Kialineq centre East Greenland. Contrib. Mineral. Petrol. 92, 57-70.

Chavagnac, V., Jahn, B.-M., 1996. Coesite-bearing eclogites from the Bixiling complex, Dabie Mountains, China: Sm-Nd ages, geochemical characteristics and tectonics implications. Chem. Geol. 133, 29-51.

Chen, J.F., Xie, Z., Li, H.M., Zhang, X.D., Zhou, T.X., Park, Y.S., Ahn, K.S., Chen, D.G., Zhang, X., 2003. U-Pb zircon ages for a collision-related K-rich complex at Shidao in the Sulu ultrahigh pressure terrane, China. Geochem. J. 37, 35-46.

Compston, W., Williams, I.S., Kirschvink, J.L., Zhang, Z., Ma, G., 1992. Zircon U-Pb ages for the Early Cambrian time-scale. J. Geol. Soc. (Lond.) 149, 148-171.

Cong, B.-L., 1996. Ultrahigh-Pressure Metamorphic Rocks in the Dabieshan-Sulu Region of China. Science Press, Beijing. $224 \mathrm{pp}$.

Davies, J.H., von Blanckenburg, F., 1995. Slab breakoff: a model of lithosphere detachment and its test in the magmatism and deformation of collisional orogens. Earth Planet. Sci. Lett. 129, $85-102$.

DePaolo, D.J., 1981. Trace element and isotopic effects of combined wallrock assimilation and fractionation crystallization. Earth Planet. Sci. Lett. 53, 189-202.

Devey, C.W., Cox, K.G., 1987. Relationships between crustal contamination and crystallization in continental flood basalt magmas with special reference to the Deccan Traps of the western Ghats, India. Earth Planet. Sci. Lett. 84, 59-68.

Dorais, M.J., 1990. Compositional variations in pyroxenes and amphiboles of the Belknap Mountain complex, New Hamp- shire: evidence for origin of silica-saturated alkaline rocks. Am. Mineral. 75, 1092-1105.

Eby, G.N., 1990. The A-type granitoids; a review of their occurrence and chemical characteristics and speculations on their petrogenesis. Lithos 26, 115-134.

Enami, M., Zang, Q., 1993. High-pressure eclogite from northern Jiangsu and southern Shandong province, eastern China. J. Metamorph. Geol. 11, 589-603.

England, P., Houseman, G., 1989. Extension during continental convergence, with application to the Tibetan Plateau. J. Geophys. Res. 94, 17561-17579.

Falloon, T.J., Green, D.H., Hatton, C.J., Harris, K.L., 1988. Anhydrous partial melting of a fertile and depleted peridotite from 2 to $30 \mathrm{kbar}$ and application to basalt petrogenesis. J. Petrol. 29, 1257-1282.

Fan, W.M., Guo, F., Wang, Y.J., Lin, G., Zhang, M., 2001. Postorogenic bimodal volcanism along the Sulu orogenic belt in eastern China. Phys. Chem. Earth, Part A Solid Earth Geol. 26, $733-746$.

Foley, S.F., Venturelli, G., Green, D.H., Toscani, L., 1987. The ultrapotassic rocks: characteristics, classification and constraints for petrogenetic models. Earth-Sci. Rev. 24, $81-134$.

Furman, T., Graham, D., 1999. Erosion of lithospheric mantle beneath the East African Rift system: geochemical evidence from the Kivu volcanic province. Lithos 48, 237-262.

Gao, S., Luo, T.-C., Zhang, B.-R., Zhang, H.-F., Han, Y.-W., Zhao, Z.-D., Hu, Y.-K., 1998a. Chemical composition of the continental crust as revealed by studies in East China. Geochim. Cosmochim. Acta 62, 1959-1975.

Gao, S., Zhang, B.-R., Jin, Z.-M., Kern, H., Luo, T.-C., Zhao, Z.-D., 1998b. How mafic is the lower continental crust? Earth Planet. Sci. Lett. 106, 101-117.

Guo, F., Fan, W.M., Wang, Y.J., Lin, G., 2001a. Late Mesozoic Mafic intrusive complexes in North China block: constraints on the nature of subcontinental lithospheric mantle. Phys. Chem. Earth, Part A Solid Earth Geol. 26, 159-771.

Guo, J.H., Chen, F.K., Zhang, X.M., Fan, H.R., Cong, B.L., 2001 b. Origin of granitoid and post-collisional tectonic process of the Sulu UHP belt: zircon U-Pb geochronology and geochemistry. Abstract of Symposium on Continental Subduction, Delamination and Timing of Lithospheric Thinning, Xi'an, pp. 99-102. in Chinese.

Hacker, B., Ratschbacher, L., Webb, L., Ireland, T., Walker, D., Dong, S., 1998. U/Pb zircon ages constrain the architecture of the ultrahigh-pressure Qinling-Dabie orogen, China. Earth Planet. Sci. Lett. 161, 215-230.

Harris, N.B.W., 1985. Alkaline complexes from the Arabian Shield. In: Black, R., Bowden, P. (Eds.), Alkaline Ring Complexes in Africa, J. Afr. Earth Sci. vol. 3, pp. 83-88.

Hickey, R., Frey, F.A., 1982. Geochemical characteristics of boninite series volcanics: implications for their source. Geochim. Cosmochim. Acta 49, 1797-1811.

Hirajima, T., Ishiwatari, A., Cong, B., Zhang, R., Banno, S., Nozaka, T., 1990. Coesite from Mengzhong eclogite at Donghai county, northern Jiangsu province, China. Mineral. Mag. 54, 579-583. 
Hirajima, T., Zhang, R.Y., Li, J.J., Cong, B.L., 1992. Nyboite from the Donghai area, Jiangsu province, eastern China. Mineral. Mag. 56, 37-46.

Hofmann, A., Jochum, K., Seufert, M., White, M., 1986. Nb and Pb in oceanic basalts: new constraints on mantle evolution. Earth Planet. Sci. Lett. 33, 33-45.

Houseman, G., England, P., 1993. Crustal thickening versus lateral expulsion in the India-Asian continental collision. J. Geophys. Res. 98, 12233-12249.

Houseman, G.A., McKenzie, D.P., Molnar, P., 1981. Convective instability of a thickened boundary layer and its relevance for the thermal evolution of continental convergent belts. J. Geophys. Res. 86, 6115-6132.

Huang, C., 1978. An outline of the tectonic characteristics of China. Eclogae Geol. Helv. 71, 611-635.

Huang, W.L., Wyllie, P.J., 1981. Phase relationships of S-type granite with $\mathrm{H}_{2} \mathrm{O}$ to 35 kbar: muscovite granite from Harney Peak, South Dakota. J. Geophys. Res. 86, 10515-10529.

Jahn, B.M., Wu, F.Y., Lo, C.H., Tsai, C.H., 1999. Crust-mantle interaction induced by deep subduction of the continental crust: geochemical and $\mathrm{Sr}-\mathrm{Nd}$ isotopic evidence from post-collisional mafic-ultramafic intrusions of the northern Dabie complex, central China. Chem. Geol. 157, 119-146.

Kato, T., Enami, A., Zhai, M., 1997. Ultrahigh-pressure marble and eclogite in the Su-Lu ultrahigh-pressure terrane, eastern China. J. Metamorph. Geol. 15, 169-182.

Le Maitre, R.W., 2002. Igneous Rocks: A Classification and Glossary of Terms, (2nd). Cambridge University Press, Cambridge. $236 \mathrm{pp}$.

Lee, C.Y., Tsai, J.H., Ho, H.H., Yang, T.F., Chung, S.L., Chen, C.H., 1997. Quantitative analysis in rock samples by an X-ray fluorescence spectrometer (I) major elements. Program with Abstracts of 1997 Annual Meeting of Geological Society of China, Taipei, pp. 418-420. in Chinese.

Li, S., Xiao, Y., Liu, D., Chen, Y., Ge, N., Zhang, Z., Sun, S., Cong, B., Zhang, R., Hart, S.R., Wang, S., 1993a. Collision of the North China and Yangtze blocks and formation of coesite-bearing eclogites: timing and processes. Chem. Geol. 109, 89-111.

Li, S.G., Chen, Y.Z., Ge, N.J., Liu, D.L., Zhang, Z.M., Zhang, Q.D., Zhao, D.M., 1993b. U-Pb zircon ages of eclogite and gneiss from Jiaonan group in Qingdao area. Chin. Sci. Bull. 38, 1773-1777. in Chinese.

Li, Q., Li, S., Zheng, Y.-F., Li, H., Massone, H.J., Wang, Q., 2003. A high precision $\mathrm{U}-\mathrm{Pb}$ age of metamorphic rutile in coesite-bearing eclogite from the Dabie Mountains in central China: a new constraint on the cooling history. Chem. Geol. 200, 255-265.

Lin, J.Q., Tan, D.J., Chi, X.G., Bi, L.J., Xie, C.F., Xu, W.L., 1992. Mesozoic Granites in Jiao-Liao Peninsula. Science Press, Beijing, pp. 208. in Chinese with English abstract.

Liu, J., Xu, Z., Liou, J.G., Song, B., 2004. SHRIMP U-Pb ages of ultrahigh-pressure and retrograde metamorphism of gneisses, south-western Sulu terrane, eastern China. J. Metamorph. Geol. 22, 315-326.

Litvinovsky, B.A., Jahn, B.M., Zanvilevich, A.N., Shadaev, M.G., 2002. Crystal fractionation in the petrogenesis of an alkali monzodiorite-syenite series: the Oshurkovo plutonic sheeted complex, Transbaikalia, Russia. Lithos 64, 97-130.
Lubala, R.T., Frick, C., Roders, J.H., Walraven, F., 1994. Petrogenesis of syenites and granites of the Schiel Alkaline complex, Northern Transvaal, South Africa. J. Geol. 102, 307-309.

Lynch, D.J., Musselman, T.E., Gutmann, J.T., Patchett, P.J., 1993. Isotopic evidence for the origin of Cenozoic volcanic rocks in the Pinacate volcanic field, northwestern Mexico. Lithos 29, 295-302.

Marsh, J.S., 1989. Geochemical constraints on coupled assimilation and fractional crystallization involving upper crustal compositions and continental tholeiitic magma. Earth Planet. Sci. Lett. $92,78-80$.

Middlemost, E.A.K., 1972. A simple classification of volcanic rocks. Bull. Volcanol. 36, 382-397.

Middlemost, E.A.K., 1994. Naming materials in the magma/igneous rock system. Earth-Sci. Rev. 74, 193-227.

Miller, C., Schuster, R., Klötzli, U., Frank, W., Purtscheller, F., 1999. Post-collisional potassic and ultrapotassic magmatism in SW Tibet: geochemical and $\mathrm{Sr}-\mathrm{Nd}-\mathrm{Pb}-\mathrm{O}$ isotopic constraints for mantle source characteristics and petrogenesis. J. Petrol. 40, 1399-1424.

Mingram, B., Trumbull, R.B., Littman, S., Gertenberger, H., 2000. A petrogenetic study of anorogenic felsic magmatism in the Cretaceous Paresis ring complex, Namibia: evidence for mixing of crust and mantle-derived components. Lithos 54, 1-22.

Nelson, D.R., 1997. Compilation of SHRIMP U-Pb zircon data 1996. Geological Survey of Western Australia Record 1997/2.

Parker, D.F., 1983. Origin of the trachyte-quartz trachyte-peralkalic rhyolite suite of the Oligocene Paisano volcano, Trana-Pecos Texas. Geol. Soc. Amer. Bull. 94, 614-629.

Rapp, R.P., Shimizu, N., Norman, M.D., 2003. Growth of early continental crust by partial melting of eclogite. Nature 425 , 605-609.

Renne, P.R., Swisher, C.C., Deino, A.L., Karner, D.B., Owens, T.L., DePaolo, D.J., 1998. Intercalibration of standards, absolute ages and uncertainties in ${ }^{40} \mathrm{Ar} /{ }^{39} \mathrm{Ar}$ dating. Chem. Geol. 145, 117-152.

Rollinson, H.R., 1993. Using Geochemical Data: Evaluation, Presentation, Interpretation. Longmans Singapore Publishers (Pte), Singapore.

Schmidt, M.W., Poli, S., 2003. Generation of mobile components during subduction of oceanic crust. Treatise Geochem. 3, $567-591$.

Sheppard, S., 1995. Hybridization of shoshonitic lamprophyre and calc-alkaline granite magma in the Early Proterozoic Mt. Bundey igneous suite, Northern Territory. Aust. J. Earth Sci. 42, $173-185$.

Sun, S.S., McDonough, W.F., 1989. Chemical and isotopic systematics of oceanic basalts: implications for mantle composition and processes. In: Saunders, A.D., Norry, M.J. (Eds.), Magmatism in the Ocean Basins, Spec. Publ.-Geol. Soc., vol. 42 , pp. $313-345$.

Sun, W., Li, S., Chen, Y., Li, Y., 2002. Timing of synorogenic granitoids in the south Qinling, central China: constraints on the evolution of the Qinling-Dabie orogenic belt. J. Geol. 110, $457-468$.

Sutcliffe, R.H., Smith, A.R., Doherty, W., Barnett, R.L., 1990. Mantle derivation of Archean amphibole-bearing granitoids 
and associated mafic rocks: evidence from the southern Superior Province, Canada. Contrib. Mineral. Petrol. 105, 255-274.

Sylvester, P.J., 1989. Post-collisional alkaline granites. J. Geol. 97, $261-280$.

Thorpe, R.S., Tindle, A.G., 1992. Petrology and petrogenesis of a Tertiary bimodal dolerite-peralkaline/subalkaline-trachyte/rhyolite dyke association from Lundy, Bristol Channel, UK. Geol. J. 27, 101-117.

Turner, S., Arnaud, N., Liu, J., Rogers, N., Hawkesworth, C., Harris, N., Kelley, S., Van Calsteren, P., Deng, W., 1996. Postcollision, shoshonitic volcanism on the Tibetan Plateau: implications for convective thinning of the lithosphere and the source of ocean island basalts. J. Petrol. 37, 45-71.

Wang, X.M., Zhang, R.Y., Liou, J.G., 1995. UHPM terrane in east central China. In: Coleman, R., Wang, X. (Eds.), Ultrahigh Pressure Metamorphism. Cambridge University Press, pp. 356-390.

Wang, L.G., Qiu, Q., McNaughton, N.J., Groves, D.I., Luo, Z., Huang, J., Miao, L., Liu, Y., 1998. Constraints on crustal evolution and gold metallogeny in the Northwestern Jiaodong Peninsula, China, from SHRIMP U-Pb zircon studies of granitoids. Ore Geol. Rev. 13, 275-291.

Wang, K.L., Chung, S.L., O'Reilly, S.Y., Sun, S.S., Shinjo, R., Chen, C.H., 2004. Geochemical constraints for the genesis of post-collisional magmatism and the geodynamic evolution of the northern Taiwan region. J. Petrol. 45, 975-1011.

Webb, L.E., Hacker, B.R., Ratschbacher, L., McWilliams, M.O., Dong, S., 1999. Thermo-chronological constraints on deformation and cooling history of high- and ultrahigh-pressure rocks in the Qinling-Dabie orogen, eastern China. Tectonics $18,621-638$.

Whalen, J.B., Currie, K.L., Chappell, B.W., 1987. A-type granites; geochemical characteristics, discrimination and petrogenesis. Contrib. Mineral. Petrol. 95, 407-419.

Williams, H.M., Turner, S.P., Pearce, J.A., Kelley, S.P., Harris, N.B.W., 2004. Nature of the source regions for post-collisional, potassic magmatism in southern and northern Tibet from geochemical variations and inverse trace element modelling. J. Petrol. 45, 555-607.

Xu, J.W., Zhu, G., 1994. Tectonic models of the Tan-Lu fault zone, eastern China. Geol. Rev. 36, 771-784. (in Chinese with English abstract).

Xu, S., Okay, A.I., Ji, S., Sengör, A.M.C., Su, W., Liu, Y., Jiang, L., 1992. Diamond from the Dabie Shan metamorphic rocks and its implication for tectonic setting. Science 256, $80-82$.
Yang, J.H., 2000. Age and metallogenic dynamics of gold mineralization in Jiaodong Peninsula, eastern China (in Chinese with English abstract). $\mathrm{PhD}$ thesis, Institute of Geology and Geophysics, Chinese Academy of Sciences, 133 pp.

Yang, J., Smith, D.C., 1989. Evidence for a former sanidinecoesite eclogite at Lanshantou, eastern China, and the recognition of the Chinese Su-Lu Coesite-Eclogite Province. Terra Nova Abstract 1, 26.

Yang, J., Godard, G., Kienast, J.R., Lu, Y., Sun, J., 1993. Ultrahighpressure $60 \mathrm{kbar}$ magnesite-bearing garnet peridotites from northeastern Jiangsu, China. J. Geol. 101, 541-554.

Yang, J.H., Chung, S.L., Zhai, M.G., Zhou, X.H., 2004. Geochemical and $\mathrm{Sr}-\mathrm{Nd}-\mathrm{Pb}$ isotopic compositions of mafic dikes from the Jiaodong Peninsula, China: evidence for vein-plus-peridotite melting in the lithospheric mantle. Lithos 73, 145-160.

Yao, Y.P., Ye, K., Liu, J., Cong, B., Wang, Q., 2000. A transitional eclogite- to high pressure granulite-facies overprint on coesiteeclogite at Taohang in the Sulu ultrahigh-pressure terrane, Eastern China. Lithos 52, 109-120.

Ye, K., Cong, B., Ye, D., 2000. The possible subduction of continental material to depths greater than $200 \mathrm{~km}$. Nature 407 , $734-736$.

Zhang, R.Y., Liou, J.G., Cong, B., 1994. Petrogenesis of garnetbearing ultramafic rocks and associated eclogites in the SuLu ultrahigh-P metamorphic terrane, eastern China. J. Metamorph. Geol. 12, 169-186.

Zhang, R.Y., Hirajima, T., Banno, S., Cong, B., Liou, J.G., 1995. Petrology of ultrahigh-pressure metamorphic rocks in southern Sulu region, eastern China. J. Metamorph. Geol. 13, $659-675$.

Zhang, X., Cawood, P.A., Wilde, S.A., Liu, R., Song, H., Li, W., Snee, L.W., 2003. Geology and timing of mineralization at the Cangshang gold deposit, north-western Jiaodong Peninsula, China. Miner. Depos. 38, 141-153.

Zhao, J.-X., Shiraishi, K., Ellis, D.J., Sheraton, J.W., 1995. Geochemical and isotopic studies of syenites from the Yamoto Mountains, East Antartica: implication for the origin of syenitic magmas. Geochim. Cosmochim. Acta 59, $1363-1385$.

Zheng, Y.-F., Wang, Z.-R., Li, S.-G., Zhao, Z.-F., 2002. Oxygen isotope equilibrium between eclogite minerals and its constraints on mineral Sm-Nd chronometer. Geochim. Cosmochim. Acta 66, 625-634.

Zheng, Y.-F., Fu, B., Gong, B., Li, L., 2003. Stable isotope geochemistry of ultrahigh pressure metamorphic rocks from the Dabie-Sulu orogen in China: implications for geodynamics and fluid regime. Earth-Sci. Rev. 62, 105-161. 